\title{
Buffalo Bayou Park \\ Methods
}

Research Fellow:

Amanda Aman

Adjunct Assistant Professor

University of Texas at Arlington

Research Assistant:

Yalcin Yildirim

PhD Candidate

University of Texas at Arlington

Firm Liaison:

Michael Robinson

Associate

SWA Group

This investigation was conducted as part of the Landscape Architecture Foundation's 2019 Case Study Investigation (CSI) program. CSI matches faculty-student research teams with design practitioners to document the benefits of exemplary high-performing landscape projects. Teams develop methods to quantify environmental, social, and economic benefits and produce Case Study Briefs for LAF's Landscape Performance Series.

To cite: Aman, Amanda, and Yalcin Yildirim. "Buffalo Bayou Park Methods." Landscape Performance Series. Landscape Architecture Foundation, 2019.

https://doi.org/10.31353/cs1581

The full case study can be found at: https://landscapeperformance.org/case-studybriefs/buffalo-bayou-park 


\section{Table of Contents}

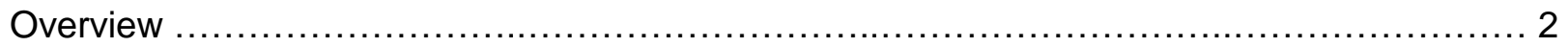

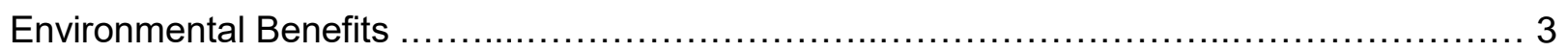

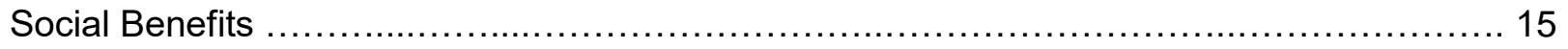

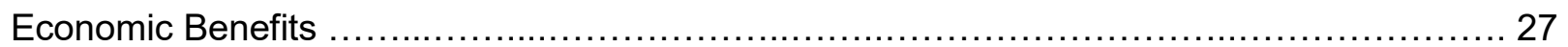

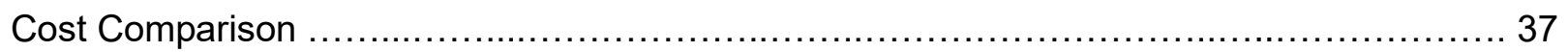

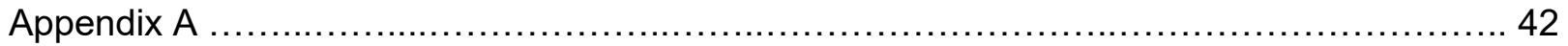

\section{Overview}

Buffalo Bayou Park is an urban green space located upstream of downtown Houston, Texas, along Buffalo Bayou, the principal drainage system for much of the city. Tested by three major floods since its opening - including Hurricane Harvey, which dropped 27 trillion gallons of water on metropolitan Houston - Buffalo Bayou Park is a precedent for resilient open-space design, planning, and operations in climate-sensitive and flood-prone coastal areas in an age of accelerated climate change with devastating potential impacts. The design of the park sought to mitigate seasonal and catastrophic flooding events while also restoring ecologies and systems, simplify and streamline maintenance procedures, improve the health and well-being of park users, and to catalyze economic revitalization in the areas adjacent to the park. The research outline below shows that since the park's opening, it has performed as designed relative to flood events, restored ecologies and promoted pollinator habitat, improved the health and well-being of park users and educated the public on flood protection, and has catalyzed development and increased property values in the areas adjacent to the park. 


\title{
Environmental Benefits
}

\section{Withstood significant flooding and avoided an estimated $\$ 2$ million in damages from Hurricane Harvey with custom-designed site fixtures and furnishings.}

\author{
Methods: \\ Site fixtures and furnishings within Buffalo Bayou Park were custom-designed to \\ withstand submersion during flood events and the impact of floating debris. Trail light \\ poles, stair handrails and guardrails were designed with higher material strength and \\ thickness, which led to higher upfront costs. This customization was necessitated by the \\ frequency of flood events the park experiences (and will continue to experience) each \\ year with the goal of limiting the costs in damages after each event. It may be assumed \\ that if off-the-shelf products had been used, they would not have withstood the effects of \\ Harvey and would have needed to be replaced.
}

\section{Calculations:}

The upfront material costs for each of these items was compared to typical off-the-shelf costs for similar fixtures and furnishings without customization. Locations, quantities, and linear footages of these items were extracted from the construction drawings, and the product costs per item/linear foot were provided by the landscape architect.

Using the high water level elevations during Hurricane Harvey (provided by the Harris County Flood Control District) at Shepherd Dr. (elevation 41.1) and Sabine St. (39.9) the two borders of the park - high water level surface elevations along the entire corridor were extrapolated. The average of these water surface elevations, $+/-40.5$, was used for the entire park. Because each light pole is 11'-0" tall from finish grade (FG) to top of fixture, three categories of impact were created for this analysis:

Total Trail Light Poles: 486

Total Submersion: Finish Grade (FG) +29 and below: 283 fixtures $283 / 486=.582 * 100=58 \%$

Partial Submersion: Finish Grade $(F G)+30$ to $+40: 122$ fixtures $122 / 486=.251 * 100=25 \%$

No Submersion: Finish Grade (FG) +40 and above: 81 fixtures (17\%) $81 / 486=.167^{*} 100=17 \%$

From this extrapolation, it was determined that approximately $83 \%$ of the light poles and fixtures (shown as an example in the calculations above) and approximately $95 \%$ of the stairs, retaining walls, and associated handrails, and guardrails were submerged and/or subject to floating debris. In order to estimate the potential costs in damages for these items should off-the-shelf items have been implemented instead, we applied this percentage to determine replacement costs. 


\section{Custom Concrete Light Pole and Fixture}

Quantity: 486

For reference/comparison: custom fixtures installed on site (pole \& fixture): $\$ 8,500$ each $486^{*} \$ 8,500=\$ 4,131,000$

Off-the-shelf fixture (pole \& fixture): $\$ 4,000$ each

$486 * \$ 4,000=\$ 1,944,000$

$\$ 1,944,000^{*} 0.83=\$ 1,613,520$ avoided

Handrails

Quantity: 1,534 If

For reference/comparison: custom handrails installed on site: $\$ 200 / / f$

$1,534^{*} \$ 200=\$ 306,800$

Off-the-shelf handrails: $\$ 115 /$ lf

$1,534 * \$ 115=\$ 176,410$

$\$ 176,410^{\star} .95=\$ 167,590$ avoided

Guardrails

Quantity: 1,083 If

For reference/comparison: custom guardrails installed on site: $\$ 350 /$ /f

$1,083^{*} \$ 350=\$ 379,050$

Off-the-shelf guardrails: $\$ 200 / \mathrm{lf}$

$1,083^{*} \$ 200=\$ 216,600$

$\$ 216,600^{*} .95=\$ 205,770$ avoided

$\$ 1,613,520+\$ 167,590+\$ 205,770=\$ 1,986,880$ avoided

Initial Cost Comparison for Custom v. Off-the-shelf:

Custom: $\$ 4,131,000+\$ 306,800+\$ 379,050=\$ 4,816,850$

Off-the-shelf: $\$ 1,944,000+\$ 176,410+\$ 216,600=\$ 2,337,010$

After one flood event (Hurricane Harvey):

Custom: $\$ 4,816,850$ (initial) $+\$ 0$ repair/replacement $=\$ 4,816,850$

Off-the-shelf: $\$ 2,337,010$ (initial) $+\$ 1,986,880$ repair/replacement $=\$ 4,323,890$

Note: These calculations take into consideration one flood event only (Hurricane Harvey). While the upfront costs were higher for these custom fixtures and furnishings, the avoided costs in damages, replacement, and repair has grown and will continue to grow with each flood event, given that the site is likely to withstand multiple flood events expected each year. 


\title{
Sources:
}

Construction documents and secondary data provided by the landscape architect, SWA.

\section{Limitations:}

The exact number of light fixtures and linear footage of handrails and guardrails that would have been replaced as a result of Hurricane Harvey was estimated based on water level elevations relative to item locations and likelihood of damage. The percentage used for this calculation is therefore an estimation.

Labor and Installation costs were not included in this analysis.

\section{Avoided an estimated $\$ 735,900$ in flood repair costs from Hurricane Harvey through installation of coir lifts.}

\begin{abstract}
Methods:
A series of riparian bank stabilization techniques were considered during the design phase of Buffalo Bayou Park in order to control for bank erosion from fluctuating water levels throughout the course of each flood season. Due to the prohibitive cost of installing more effective stabilization techniques, a majority of the bayou banks were stabilized with vegetation at a 2:1 slope where wetland species would occupy the portion of the bank that would occasionally submerge, with a native grass mix above. This decision suited the project budget as vegetated slope costs were at $\$ 72.50 / \mathrm{lf}$. The downside to this technique is that the potential for slope failure was much greater during flood events. After Hurricane Harvey, a number of these slopes failed and were in need of repair. It was determined that the repair cost for vegetated slope failures was \$748.50/lf (ref. Figures 26 and 27 under Cost Comparison for more details).

However, a few select locations along the bayou were stabilized with coir lifts (a very effective stabilization method) due to their high potential for slope failure during major flooding events. Coir lift costs were at $\$ 864.80 /$ If. The coir lifts performed extremely well during Hurricane Harvey and had no failures and therefore no associated repair costs. If these slopes had been constructed as vegetated slopes initially they likely would have failed, which would have resulted in additional repair costs.
\end{abstract}

\section{Calculations:}

Initial cost for coir lifts installation for approximately 900 If of banks:

900 lf* $^{*} 864.80 / \mathrm{lf}=\$ 778,320$

Instead:

Initial cost for banks to be stabilized with vegetation:

900 If $^{*} \$ 72.50 / \mathrm{lf}=\$ 62,250$ 
Repair cost if banks had failed during Hurricane Harvey: 900 lf $^{*} \$ 748.50$ lf $=\$ 673,650$

Total stabilization and repair cost after Hurricane Harvey: $\mathbf{\$ 7 3 5 , 9 0 0}$

This repair cost would continue to increase over time due to repetitive flood events causing additional need for slope repairs without highly effective bank stabilization techniques having been employed. For example, even with one more flood event similar to Hurricane Harvey, this could double the total repair cost to $\$ 1,471,800$. As compared to the initial cost for coir lift installation as a highly effective stabilization method, the total investment would have doubled.

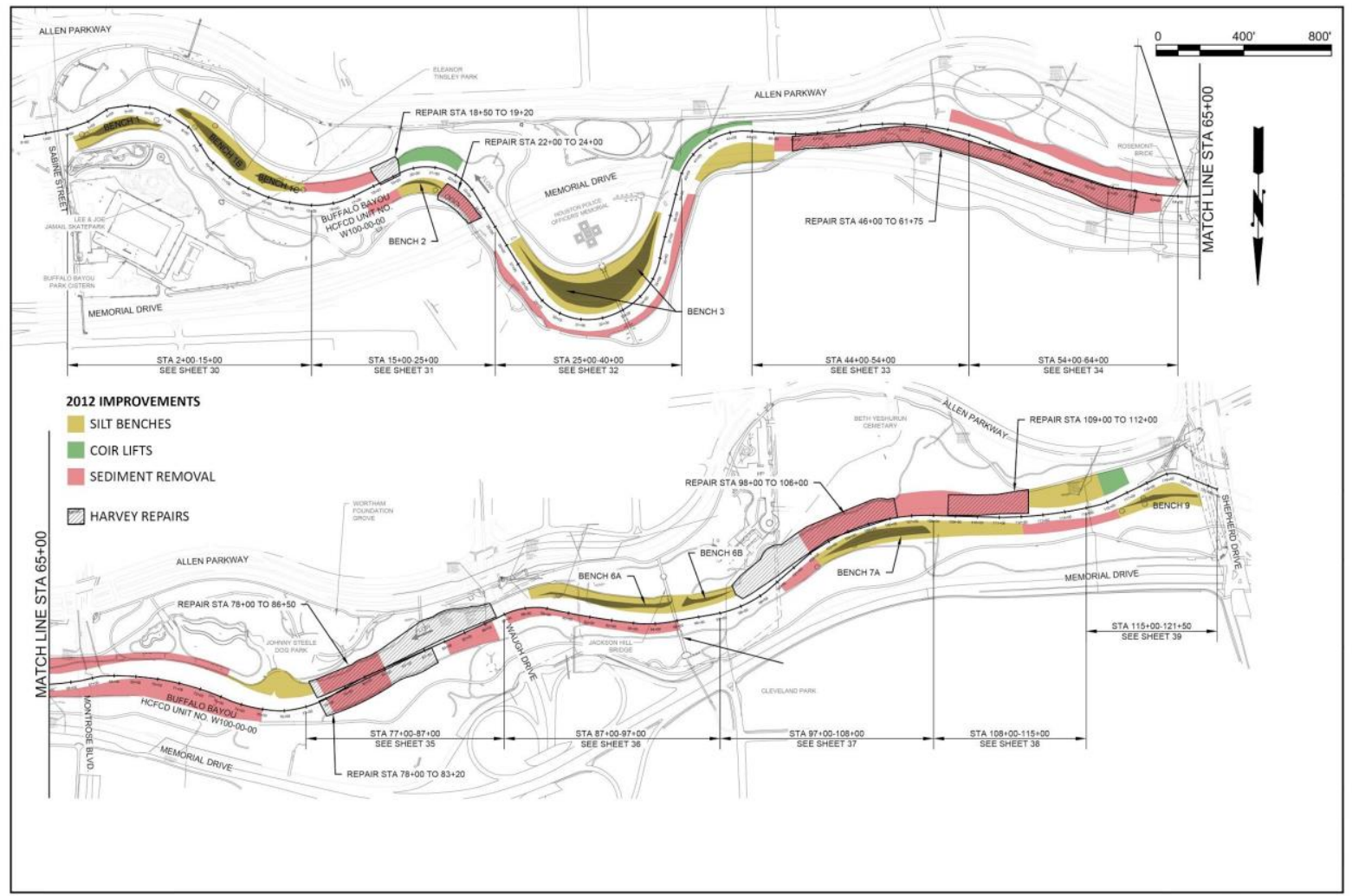

Figure 1: Coir Lift Locations Relative to Repair and Sediment Removal Locations as a Result of Hurricane Harvey (SWA)

\section{Sources:}

Stabilization data was provided by the landscape architect, SWA, and the Harris County Flood Control District (HCFCD). 


\section{Limitations:}

The costs determined for each stabilization technique are for construction costs only as they do not include soft costs, design fees, or contractor overhead.

3. Increases habitat quality within $25 \%$ of the park by providing fruit and seed sources for wildlife in $\mathbf{5 3} \%$ of newly-planted native groundcover and shrub species, nectar sources in $63 \%$, and habitat sources in $27 \%$, with $23 \%$ of these species designated as having Special Value for native pollinators.

\section{Methods:}

Three planting zones totaling 40 acres (approximately $25 \%$ of the park acreage) were analyzed for their habitat benefits, given their species compositions and potential value for habitat. These three zones include Native Woodland, Cultured Woodland, and Open Meadow. The remaining planting zones (Riparian and Turf), the bayou itself, and the trails and hardscape surfaces in the park were excluded from this analysis.

\begin{tabular}{|c|c|c|c|}
\hline BUFFALO BAYOU LANDSCAPE/HABITATZONES & & & \\
\hline ZONES & ACREAGE & TOTAL & Figure Ref. \\
\hline Native Woodland & & 9.72 & \\
\hline $25 \%$ Groundcover and Shrubs & 2.43 & & 1 \\
\hline $75 \%$ Meadow & 7.29 & & 2 \\
\hline Cultured Woodland & & 14.67 & \\
\hline $100 \%$ Meadow & 14.67 & & 2 \\
\hline Open Meadows & & 15.20 & 3 \\
\hline $100 \%$ Open Meadow & 15.20 & & \\
\hline TOTAL & & 39.59 & acres \\
\hline
\end{tabular}

Figure 2: Planting Zone Table

The Native Woodland planting zone comprises $25 \%$ groundcover and shrubs, and $75 \%$ meadow grasses and wildflowers. The Cultured Woodland planting zone comprises of $100 \%$ meadow grasses and wildflowers. The same meadow grass and wildflower seed mix was planted in both of these zones. The Open Meadow planting zone is comprised of $100 \%$ meadow grasses and wildflowers that uses a different seed mix.

The groundcover and shrub composition within the Native Woodland planting zone was analyzed first (Figure 3). Each species was cross referenced with The Xerces Society for Invertebrate Conservation Pollinator Conservation Program Special Collections Lists to determine whether or not those species had been assigned Special Value for pollinators. The Xerces Society defines Special Value as being recognized by pollination ecologists for attracting large numbers of native bees, bumble bees, honey bees, butterflies, and moths. Each species was then also cross referenced with the Lady Bird Johnson Wildflower Center plant databases to determine the habitat sources provided for wildlife including fruit and seeds, nectar, and nesting habitat. Finally, the total area of species 
within each of these habitat benefit categories was calculated as a percentage of the total groundcover and shrub area.

The meadow grass and wildflower mix within the Native and Cultured Woodland planting zones was analyzed next (Figure 4). Similar to above, each species was cross referenced with Xerces Society for Invertebrate Conservation Pollinator Conservation Program Special Collections Lists to determine whether or not those species had been assigned Special Value for pollinators. The total area of species having been assigned Special Value was then calculated as a percentage of the total meadow grass and wildflower mix area.

Finally, the meadow grass and wildflower mix within the Open Meadow planting zone was analyzed in the same manner as above (Figure 5).

As a note, given that the park's primary goal was to function properly as a flood-based public landscape, plant species and seed mixes that supported this function (the criteria being their ability to stabilize the banks of the bayou to prevent slope failure and their ability to withstand periodic inundation) and could withstand other climatic factors were given priority in certain areas of the park over pollinator and other habitat generating species.

\section{Calculations:}

For the groundcover and shrub composition analysis, the square footage of each species had to be determined first. The landscape architect provided the species mix allocation per acre (\%) and the total acreage for the Native Woodland planting zone. Each species square footage was calculated by multiplying the species mix allocation per acre (\%) by the total square footage of the groundcover and shrub composition (25\% of the Native Woodland acreage). Each species was then cross referenced with The Xerces Society for Invertebrate Conservation Pollinator Conservation Program Special Collections Lists and the Lady Bird Johnson Wildflower Center plant databases to determine habitat benefits, as discussed above under Methods. The total area of species within each of these habitat benefit categories was calculated as a percentage of the total groundcover and shrub area. 


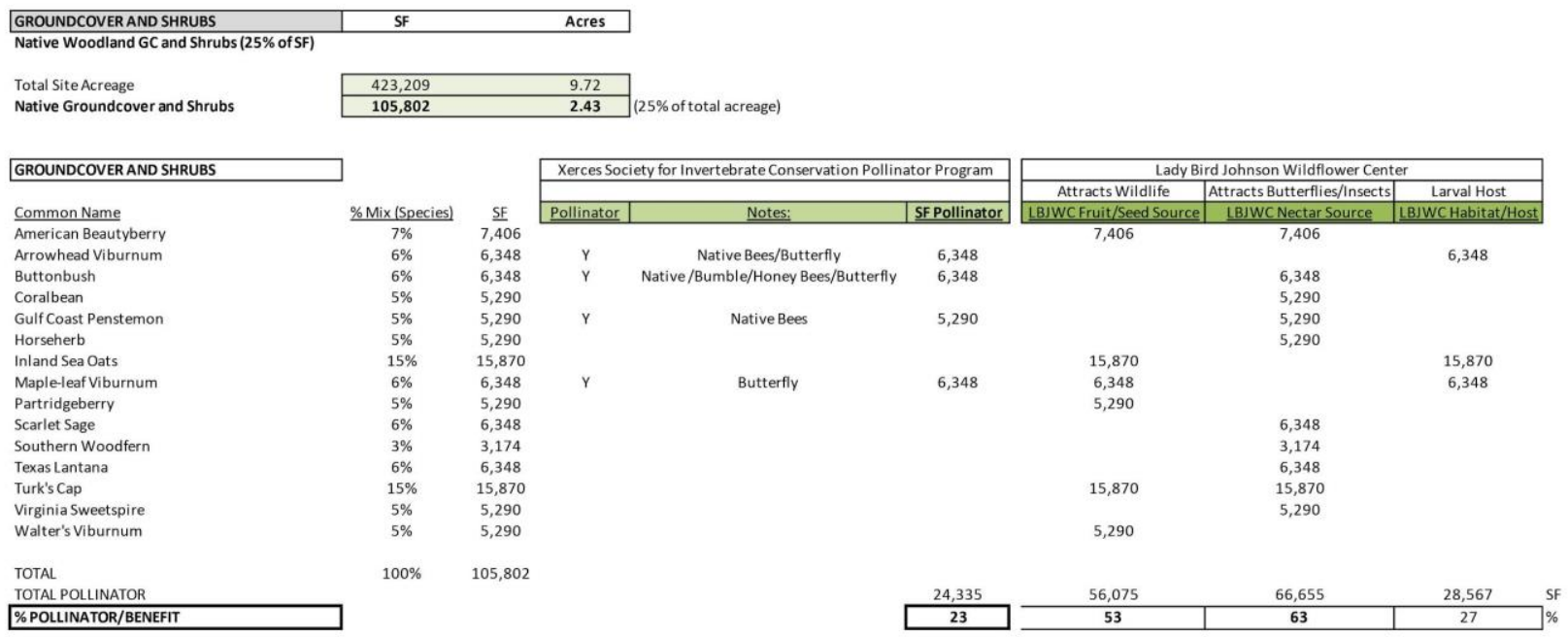

Figure 3: Calculation Spreadsheet for Species Habitat Benefits - Native Woodland Groundcover and Shrubs

Example:

American Beautyberry (7\% Species Mix)

$105,802 \mathrm{sf}^{\star} .07=7,406 \mathrm{sf}$

Fruit/Seed Source? Y

The total square footage for all species within the Fruit/Seed Source habitat benefit category was then divided by the total groundcover and shrub square footage.

$(56,075 \mathrm{sf} / 105,802 \mathrm{sf}){ }^{*} 100=53 \%$

For the meadow grass and wildflower mix analysis within the Native and Cultured Woodland planting zones and the Open Meadow planting zone, the same process was used as above. Each species was cross referenced with The Xerces Society for Invertebrate Conservation Pollinator Conservation Program Special Collections Lists only due to the potential habitat benefits being mostly pollinator-driven. 


\begin{tabular}{|c|c|c|c|c|c|}
\hline GRASS/WILDFLOWER MIXES & SF & & Acres & & \\
\hline Native Woodland Grasses (75\% of SF) & 317,552 & & 7.29 & & \\
\hline Cultured Woodland Grasses ( $100 \%$ of SF) & 639,025 & & 14.67 & & \\
\hline Grass/Wildflower Mix & 956,577 & & 21.96 & & \\
\hline GRASS/WILDFLOWER MIX & & & Xercess & ety for Invertebrate Conservation Pollina & tor Program \\
\hline Common Name & Live Seeds/SF & $\%$ of Total & Value & Notes: & SF Pollinator \\
\hline Plains Coreopsis & 11.61 & 111,059 & & & \\
\hline Black-eyed Susan & 11.23 & 107,424 & & & \\
\hline Sideoats Grama & 8.38 & 80,161 & Y & Nesting/Structure & 80,161 \\
\hline Plains Bristlegrass & 7.36 & 70,404 & & & \\
\hline Clasping Coneflower & 7.05 & 67,439 & & & \\
\hline Prairie Agalinis & 5.53 & 52,899 & & & \\
\hline Purpletop & 4.61 & 44,098 & & & \\
\hline Little Bluestem & 15.99 & 152,957 & Y & Nesting/Structure & 152,957 \\
\hline Scarlet Sage & 4.31 & 41,228 & & & \\
\hline Prairie Wildrye & 3.99 & 38,167 & & & \\
\hline Purple Three Awn & 3.54 & 33,863 & $\mathrm{Y}$ & Nesting/Structure & 33,863 \\
\hline Golden-Wave & 3.49 & 33,385 & & & \\
\hline Virginia Wildrye & 3.25 & 31,089 & & & \\
\hline Inland Seaoats & 3.12 & 29,845 & & & \\
\hline Winecup, Annual & 2.33 & 22,288 & $\mathrm{Y}$ & Native Bees & 22,288 \\
\hline Purple Coneflower & 1.04 & 9,948 & $\mathrm{Y}$ & Native Bees & 9,948 \\
\hline Cutleaf Daisy & 1.04 & 9,948 & Y & Conservation Bio Control & 9,948 \\
\hline Drummond Phlox & 0.71 & 6,792 & & & \\
\hline Butterfly Weed & 0.55 & 5,261 & $\mathrm{r}$ & Native Bees, Bumble Bees, Honey Bees & \\
\hline Purple Coneflower & 0.48 & 4,592 & Y & Native Bees & 4,592 \\
\hline Winecup & 0.35 & 3,348 & $\mathrm{Y}$ & Native Bees & 3,348 \\
\hline Pigeonberry & 0.04 & 383 & & & \\
\hline TOTAL & 100.00 & 956,577 & & & \\
\hline TOTAL BENEFITS & & & & & 317,105 \\
\hline \%SPECIAL VALUE/BENEFIT & & & & & $33 \%$ \\
\hline
\end{tabular}

Figure 4: Calculation Spreadsheet for Species Habitat Benefits - Native and Cultured Woodland Meadows

\begin{tabular}{|c|c|c|c|c|c|}
\hline MEADOW/WILDFLOWER MIXES & SF & & Acres & & \\
\hline Open Meadows (100\% of SF) & 661,800 & & 15.2 & & \\
\hline Meadow Mix & 661,800 & & 15.2 & & \\
\hline MEADOW MIX & & & Xerces $\mathrm{S}$ & iety for Invertebrate Conservation Pollina & tor Program \\
\hline Common Name & Live Seeds/SF & SF & Value & Notes: & SF Pollinator \\
\hline Sand Dropseed & 11.83 & 78,291 & $\frac{\mathrm{Y}}{\mathrm{Y}}$ & Nesting/Structure & 78,291 \\
\hline Plains Coreopsis & 5.60 & 37,061 & & & \\
\hline Clasping Coneflower & 5.51 & 36,465 & & & \\
\hline Prairie Agalinis & 5.33 & 35,274 & & & \\
\hline Purple Three Awn & 5.30 & 35,075 & $\mathrm{Y}$ & Nesting/Structure & 35,075 \\
\hline Sand Lovegrass & 4.21 & 27,862 & Y & Nesting/Structure & 27,862 \\
\hline Little Bluestem & 20.02 & 132,492 & y & Nesting/Structure & 132,492 \\
\hline Black-eyed Susan & 4.81 & 31,833 & & & \\
\hline Blue Grama & 4.57 & 30,244 & & & \\
\hline Indian Blanket & 4.06 & 26,869 & $\mathrm{Y}$ & Native Bees, Bumble Bees & 26,869 \\
\hline Lemon Mint & 2.83 & 18,729 & Y & Native Bees, Bumble Bees & 18,729 \\
\hline Mexican Hat Red & 2.72 & 18,001 & $\mathrm{Y}$ & Native Bees & 18,001 \\
\hline Scarlet Sage & 2.67 & 17,670 & & & \\
\hline Buffalograss & 2.33 & 15,420 & & & \\
\hline Purpletop & 2.17 & 14,361 & & & \\
\hline Prairie Coneflower & 2.05 & 13,567 & y & Native Bees & 13,567 \\
\hline Golden-Wave & 1.35 & 8,934 & & & \\
\hline Gulf Coast Muhly & 1.20 & 7,942 & & & \\
\hline Curly Mesquite & 1.14 & 7,545 & & & \\
\hline Texas Cupgrass & 1.11 & 7,346 & & & \\
\hline Sideoats Grama & 1.01 & 6,684 & $\mathrm{Y}$ & Nesting/Structure & 6,684 \\
\hline Bush Sunflower & 0.95 & 6,287 & & & \\
\hline Virginia Wildrye & 0.88 & 5,824 & & & \\
\hline Prairie Wildrye & 0.87 & 5,758 & & & \\
\hline Purple Coneflower & 0.79 & 5,228 & $\mathrm{Y}$ & Native Bees & 5,228 \\
\hline Lanceleaf Coreopsis & 0.72 & 4,765 & Y & Native Bees, Conservation Bio Control & 4,765 \\
\hline Drummond Phlox & 0.68 & 4,500 & & & \\
\hline Texas Bluebonnet & 0.61 & 4,037 & Y & Native Bees, Bumble Bees & 4,037 \\
\hline Pink Evening Primrose & 0.49 & 3,243 & y & Native Bees & 3,243 \\
\hline Winecup & 0.49 & 3,243 & y & Native Bees & 3,243 \\
\hline Rattlesnake Master & 0.44 & 2,912 & y & Native Bees, Conservation Bio Control & 2,912 \\
\hline Huisache Daisy & 0.34 & 2,250 & & & \\
\hline Green Sprangletop & 0.24 & 1,588 & & & \\
\hline Purple Prairie Clover & 0.19 & 1,257 & $\mathrm{y}$ & Native Bees, Bumble Bees, Honey Bees & 1,257 \\
\hline Cutleaf Daisy & 0.18 & 1,191 & y & Conservation Bio Control & 1,191 \\
\hline Texas Yellow Star & 0.15 & 993 & & & \\
\hline Gayfeather & 0.09 & 596 & y & Native Bees & 596 \\
\hline American Basketflower & 0.07 & 463 & $\mathrm{Y}$ & Native Bees & 463 \\
\hline TOTAL & 100.00 & 661,800 & & & \\
\hline TOTAL BENEFITS & & & & & 384,506 \\
\hline$\%$ SPECIAL VALUE/BENEFIT & & & & & $58 \%$ \\
\hline
\end{tabular}

Figure 5: Calculation Spreadsheet for Species Habitat Benefits - Open Meadows 


\section{Sources:}

Native groundcover and shrub species lists and breakdowns were provided by the landscape architect, SWA.

Native grass and wildflower meadow species lists and breakdowns were provided by the Katy Prairie Conservancy

"Plant Lists \& Collections." Lady Bird Johnson Wildflower Center - The University of Texas at Austin. Accessed May 18, 2019. https://www.wildflower.org/collections/.

"Pollinator Conservation Program." The Xerces Society for Invertebrate Conservation. Accessed May 18, 2019. https://xerces.org/pollinator-conservation/.

\section{Limitations:}

The plant species and breakdowns used for these calculations were based off of the original construction documents provided by the landscape architect. These calculations do not account for changes in the field during construction or ongoing maintenance, replacement, or repair.

The meadow seed mixes were designed through a series of iterations and were also altered before seeding due to species availability and other issues. The seed mixes used in this analysis reflect the original iteration. In addition, the Native and Cultured Woodland meadow mixes were designed to turnover with more shade tolerant species as the tree canopies grew in over time. The species composition that exists today may promote varied habitat results from this analysis.

Two of the three planting zones analyzed (Native Woodland and Cultured Woodland) also contain a large quantity and variety of tree species that also provide habitat value. These trees were not taken into account for this analysis.

\section{Sequesters 9.19 tons of atmospheric carbon and intercepts approximately 84,000 gallons of stormwater runoff annually in approximately 9,800 newly-planted trees.}

\section{Methods:}

i-Tree Eco v6 is a software application within a suite of tools that utilizes data to estimate ecosystem services and structural characteristics of rural and urban forests. The application provides sampling and data collection protocols, automated processing, and final reports illustrating carbon sequestration in pounds, carbon storage in pounds, and avoided runoff in cubic feet.

The landscape architect provided tree planting data for the park in five planting zones, each with defined species mix percentages per acre. The five zones include: Native Woodland, Cultured Woodland, Riparian Bayou Edge, Garden Areas, and Specimen 
Trees. Two zones, Native Woodland and Cultured Woodland, were used for this analysis as they comprise a majority of the number of trees on site and offer the most significant sequestration benefits. The breakdown for each zone was calculated for each species by multiplying the total number of trees specified per acre by the species mix percentage, which was then multiplied by the size mix percentage. The species and DBH (diameter at breast height) for each individual tree (the result of this breakdown) were then entered into i-Tree.

For example, the landscape architect noted that the canopy trees within the Native Woodland zone were to be planted at 300 trees/acre. Sweetgum trees were to represent $11 \%$ of this total. Additionally, $8 \%$ of sweetgums were to be 65 gallon-sized trees.

$300^{\star} .11^{*} .08=2.6465$-gallon sweetgum trees

This calculation was then repeated for each species and for each species size in order to generate a full breakdown per acre per zone. As a note, the research team had to convert gallons to DBH in order to complete the correct input for iTree using the following conversions provided by the landscape architect:

$65 \mathrm{gal}=3$ " caliper $/ \mathrm{DBH}, 30 \mathrm{gal}=2.5$ " caliper $/ \mathrm{DBH}, 15 \mathrm{gal}=1.5 "$ caliper/DBH, $5 \mathrm{gal}=1$ " caliper $/ \mathrm{DBH}, 1 \mathrm{gal}=0.5$ " caliper

\section{Calculations:}

i-Tree's database assigns values for each tree species and size types. It uses a calculation to determine $\mathrm{CO} 2$ sequestered per tree $(\mathrm{kg})$, and avoided runoff is estimated based on local weather data from the nearest weather station.

Each zone (Native Woodland and Cultured Woodland) was analyzed in i-Tree separately, as listed below. The data for each zone was input for one (1) acre; the benefits were then extrapolated for the entire zone by multiplying each value by the zone acreage.

Native Woodland

Carbon Sequestration: $646.1 \mathrm{lbs}$ (i-Tree Eco v6) for 400 trees of 10 species representing 1 acre of Native Woodland zone

$646.1 \mathrm{Ibs}^{*} 9.72$ acres (acreage of Native Woodland zone) $=6,280 \mathrm{lbs}=\mathbf{3 . 1 4}$ tons

Avoided Runoff: $450.4 \mathrm{cu}$. ft./year (i-Tree Eco v6) for 400 trees of 10 species

representing 1 acre of Native Woodland zone

$450.4 \mathrm{cu}$. ft./year ${ }^{*} 9.72$ acres (acreage of Native Woodland zone) $=4,378 \mathrm{cu}$. ft. $=$ 32,750 gallons 


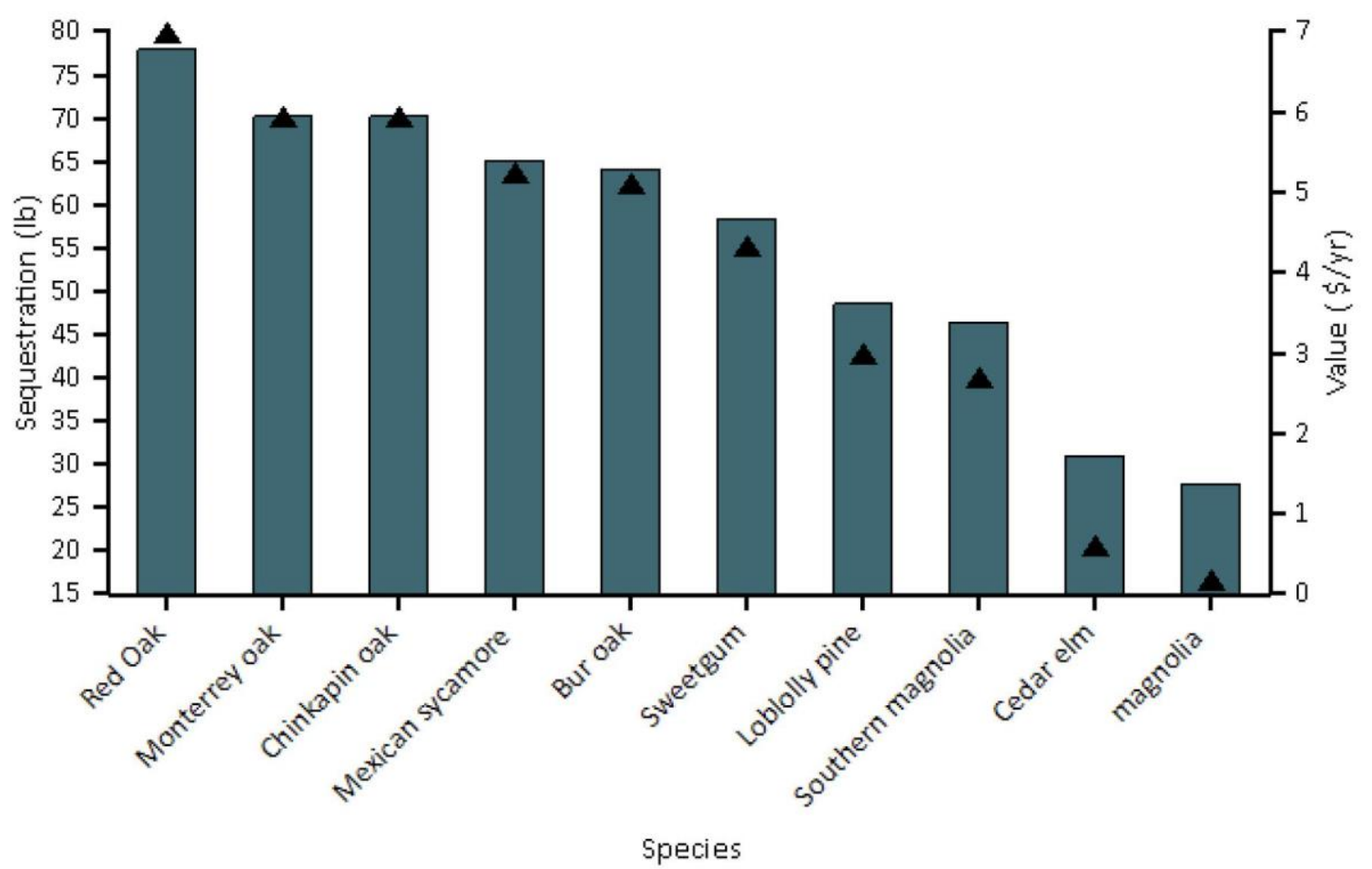

Figure 6: Estimated Gross Annual Carbon Sequestration for Species with the Greatest Sequestration (iTree Eco v6)

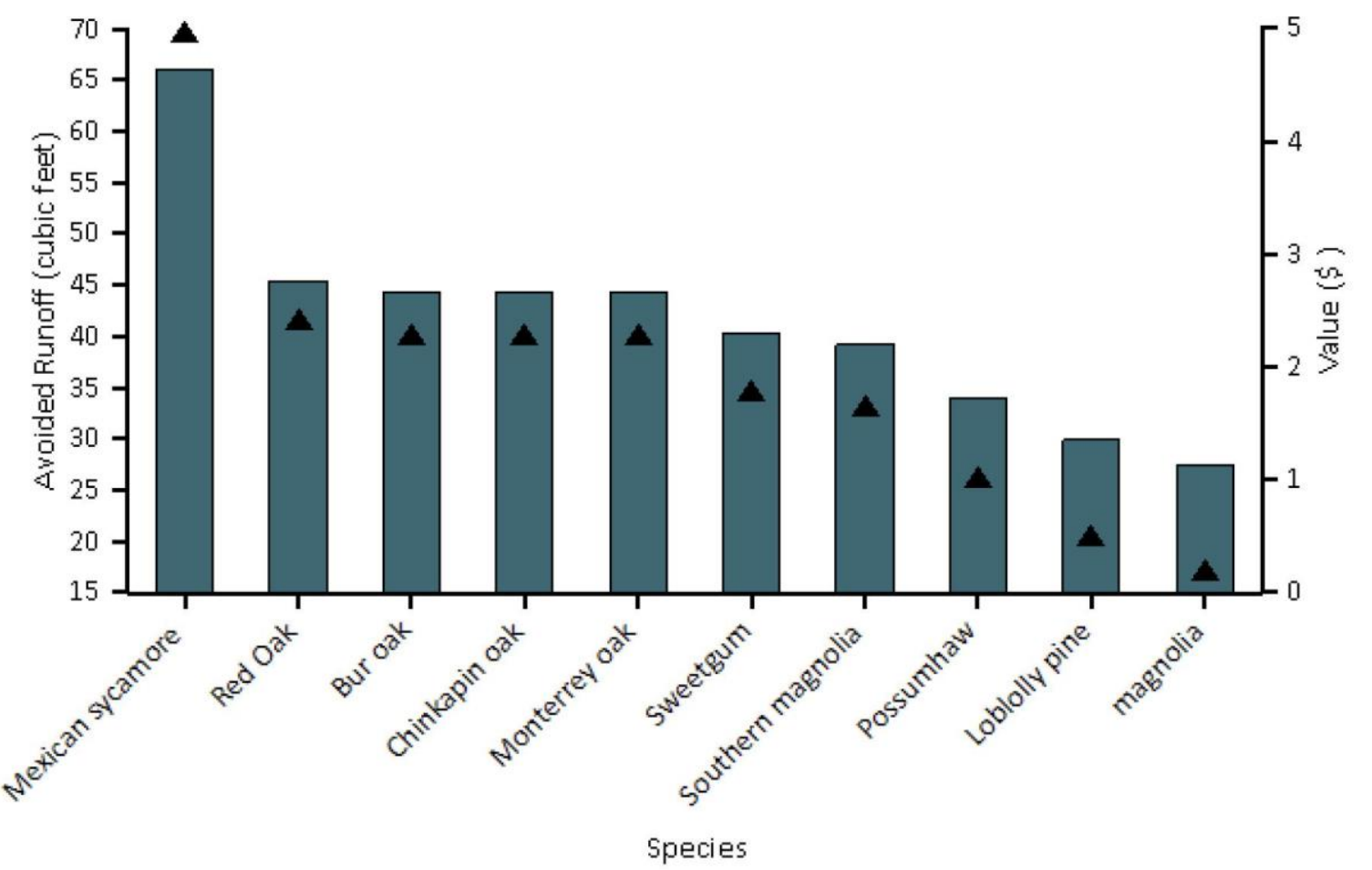

Figure 7: Avoided Runoff for Species with the Greatest Overall Impact on Runoff (i-Tree Eco v6) 
Cultured Woodland

Carbon Sequestration: $824.5 \mathrm{lbs}$ (i-Tree Eco v6) for 400 trees of 8 species representing 1 acre of Cultured Woodland zone

$824.5 \mathrm{lbs}^{*} 14.67$ acres (acreage of Cultured Woodland zone) $=12,095 \mathrm{lbs}=6.05$ tons

Avoided Runoff: 468.2 cu. ft./year (i-Tree Eco v6) for 400 trees of 8 species representing 1 acre of Cultured Woodland zone

$468.2 \mathrm{cu}$. ft./year*14.67 acres (acreage of Cultured Woodland zone) $=6,869 \mathrm{cu}$.

$\mathrm{ft} .=51,384$ gallons

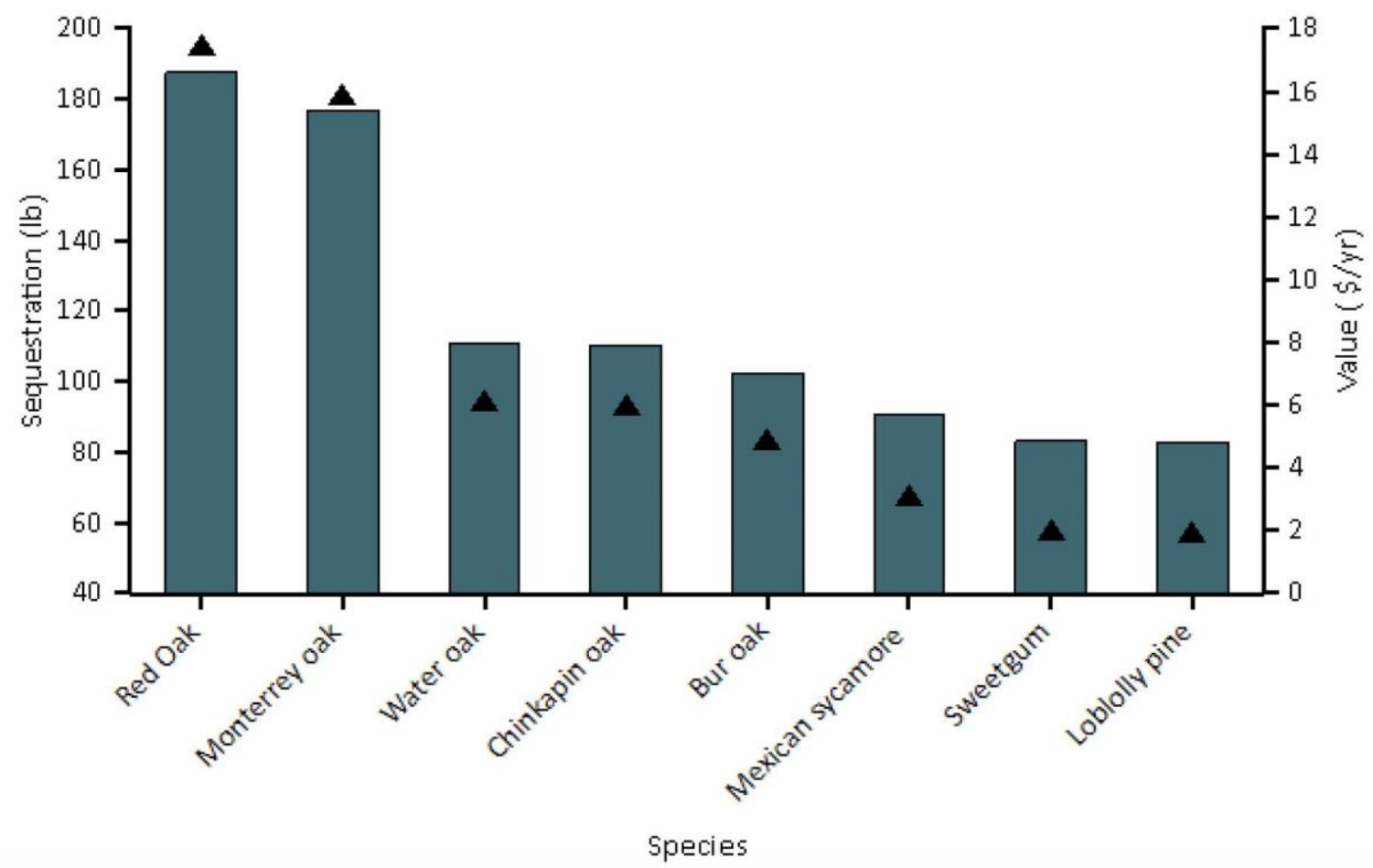

Figure 8: Estimated Gross Annual Carbon Sequestration for Species with the Greatest Sequestration (iTree Eco v6) 


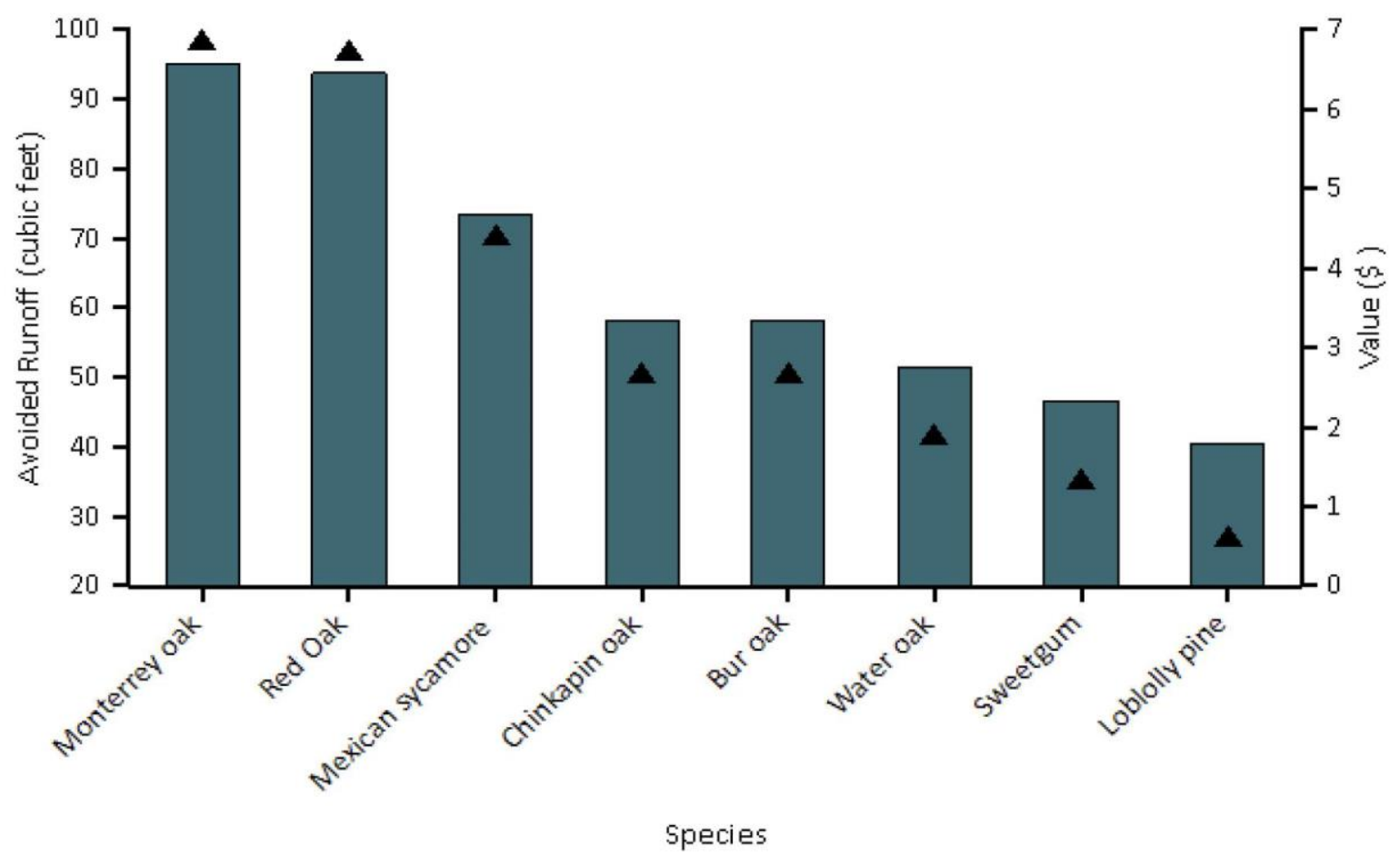

Figure 9: Avoided Runoff for Species with the Greatest Overall Impact on Runoff (i-Tree Eco v6)

3.14 tons +6.05 tons $=9.19$ tons

32,750 gallons $+51,384$ gallons $=\mathbf{8 4 , 1 3 4}$ gallons

\section{Sources:}

i-Tree Eco v6. Accessed May 14, 2019. https://www.itreetools.org/eco/index.php

Tree species lists and breakdowns were provided by the landscape architect, SWA.

\section{Limitations:}

The tree species and breakdowns used for these calculations were based off of the original construction documents provided by the landscape architect. These calculations do not account for changes in the field during construction or ongoing maintenance, replacement, or repair. Additionally, two planting zones were used for this calculation as mentioned above (Native Woodland and Cultured Woodland) which comprise a majority of the trees on site with significant sequestration benefits. However, the remaining zones (Riparian Bayou Edge, Garden Areas, and Specimen Trees) were not used in this calculation.

Average species DBH rather than each individual tree DBH was used for the calculations. Therefore, the result is an approximation, not an exact value. 
Additionally, i-Tree does not take into account groundcover and while shrubs can be taken into account, they were not included in this analysis. The benefits discussed above will increase over time.

\section{Social Benefits}

\section{Attracted an estimated 12,000 daily visitors over 11 fall days in 2016 . From June 2018 to May 2019, average daily bike share use of stations adjacent to the park ranged from 619 in February to 1,064 in April.}

\section{Methods:}

User counts from bike share companies were obtained from June of 2018 to June of 2019 and were compared to pedestrian and cyclist user counts collected in September and October of 2016.

\section{Calculations:}

Bike share data was collected from three companies with stations present in/near the park: BCycle, Bike Barn, and EaDo. Collectively, these companies have thirteen station locations throughout and surrounding the park for users to access. The data collected was categorized by monthly bike rentals per station from June of 2018 to June of 2019 . Each monthly total was then divided by 30 (average days per month) to determine the daily average for bike rentals. The daily averages per month were then used to determine an overall daily average. The 5 stations immediately adjacent to the park were used to determine the final daily average.

Pedestrians and cyclists were counted on trails within the park by temporary trail counters (TRAFx Infrared Trail Counters: Generation III) by the Houston-Galveston Area Council. This technology does not differentiate between pedestrians and cyclists therefore the total number of users is an undetermined mix. This data was collected from September 30, 2016 to October 10, 2016 and determined an estimated 11,945 daily users. 


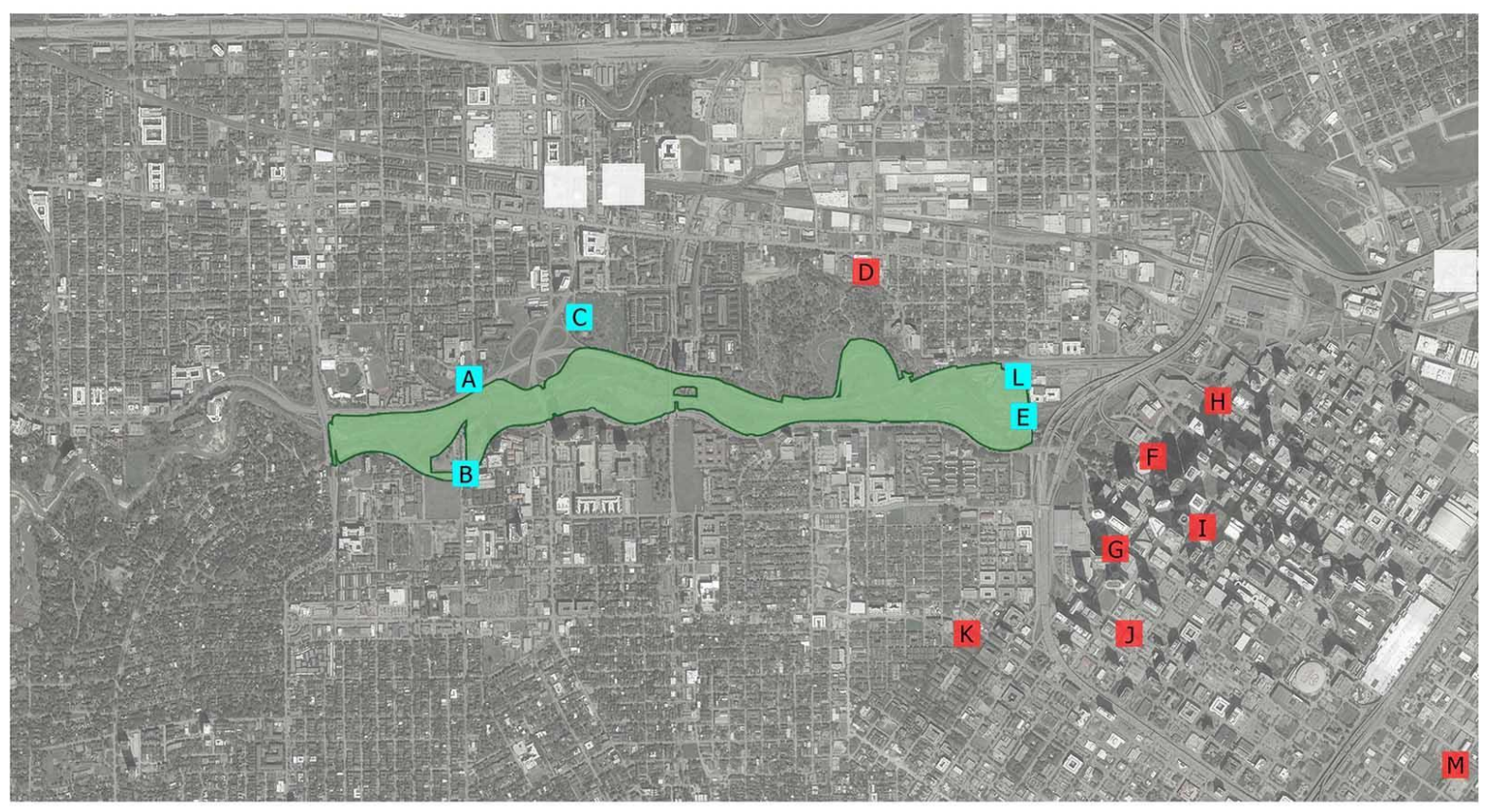

MAP KEY

A) Jackson Hill \& Memorial Drive (BCycle)

F) City Hall (BCycle)

K) West Gray \& Baldwin (BCycle)

B) Lost Lake (BCycle)

G) Clay \& Smith (BCycle)

C) Spotts Park (BCycle)

D) Washington (BCycle)

H) Smith \& Capitol (BCycle)

E) Sabine Bridge (BCycle)

I) Lamar \& Milam (BCycle)

L) Bayou Rentals (BikeBarn)

M) Downtown (EaDo)

J) Tellepsen (BCycle)

Figure 10: Bike Share Station Locations

\begin{tabular}{|c|c|c|c|c|c|c|c|c|c|c|c|c|c|c|}
\hline Company & Bike Station Name & 19-May & 19-Apr & 19-Mar & 19-Feb & 19-Jan & 18-Dec & 18-Nov & $18-0 \mathrm{ct}$ & 18-Sep & 18-Aug & 18-Jul & 18-Jun & Daily Average \\
\hline \multirow{11}{*}{ BCycle } & Jackson Hill & 403 & 527 & 442 & 257 & 340 & 225 & 286 & 402 & 329 & 447 & 474 & 416 & \\
\hline & Lost Lake & 469 & 412 & 358 & 184 & 307 & 228 & 223 & 386 & 240 & 297 & 371 & 352 & \\
\hline & Spotts Park & 809 & 719 & 746 & 366 & 661 & 436 & 408 & 526 & 330 & 592 & 616 & 561 & \\
\hline & Washington & 154 & 126 & 135 & 76 & 128 & 84 & 109 & 147 & 61 & 70 & 151 & 135 & \\
\hline & Sabine Bridge & 2641 & 2960 & 2708 & 1589 & 2016 & 1705 & 1546 & 2119 & 1417 & 2333 & 2216 & 2291 & \\
\hline & City Hall & 557 & 388 & 328 & 236 & 257 & 216 & 215 & 339 & 376 & 395 & 408 & 454 & \\
\hline & Clay \& Smith & 377 & 320 & 200 & 169 & 194 & 94 & 148 & 234 & 250 & 296 & 336 & 243 & \\
\hline & Smith \& Capitol & 314 & 293 & 211 & 113 & 238 & 148 & 197 & 239 & 163 & 249 & 305 & 292 & \\
\hline & Lamar \& Milam & 446 & 455 & 332 & 212 & 181 & 275 & 231 & 265 & 270 & 351 & 351 & 343 & \\
\hline & Tellepsen & 350 & 384 & 280 & 210 & 198 & 179 & 240 & 354 & 254 & 262 & 254 & 361 & \\
\hline & West Gray \& Baldwin & 488 & 483 & 400 & 248 & 314 & 254 & 211 & 365 & 276 & 298 & 381 & 403 & \\
\hline BikeBarn & Bayou Rentals & 700 & 700 & 700 & 700 & 700 & 700 & 700 & 700 & 700 & 700 & 700 & 700 & \\
\hline \multirow{3}{*}{ EaDo } & Downtown & 41 & 41 & 41 & 41 & 41 & 42 & 42 & 42 & 42 & 42 & 42 & 42 & \\
\hline & Monthly Total & 7749 & 7808 & 6881 & 4401 & 5575 & 4586 & 4556 & 6118 & 4708 & 6332 & 6605 & 6593 & \\
\hline & Daily Average Per Month & 258 & 260 & 229 & 147 & 186 & 153 & 152 & 204 & 157 & 211 & 220 & 220 & 200 \\
\hline
\end{tabular}

Figure 11: Bike Share Counts - All Stations (2018 - 2019) 


\begin{tabular}{|c|c|c|c|c|c|c|c|c|c|c|c|c|c|c|}
\hline Company & Bike Station Name & 19-May & 19-Apr & 19-Mar & 19-Feb & 19-Jan & 18-Dec & 18-Nov & 18-Oct & 18-Sep & 18-Aug & 18-Jul & 18-Jun & Daily Average \\
\hline \multirow{4}{*}{ BCycle } & Jackson Hill & 403 & 527 & 442 & 257 & 340 & 225 & 286 & 402 & 329 & 447 & 474 & 416 & \\
\hline & Lost Lake & 469 & 412 & 358 & 184 & 307 & 228 & 223 & 386 & 240 & 297 & 371 & 352 & \\
\hline & Spotts Park & 809 & 719 & 746 & 366 & 661 & 436 & 408 & 526 & 330 & 592 & 616 & 561 & \\
\hline & Sabine Bridge & 2641 & 2960 & 2708 & 1589 & 2016 & 1705 & 1546 & 2119 & 1417 & 2333 & 2216 & 2291 & \\
\hline \multirow[t]{3}{*}{ BikeBarn } & Bayou Rentals & 700 & 700 & 700 & 700 & 700 & 700 & 700 & 700 & 700 & 700 & 700 & 700 & \\
\hline & Monthly Total & 5022 & 5318 & 4954 & 3096 & 4024 & 3294 & 3163 & 4133 & 3016 & 4369 & 4377 & 4320 & \\
\hline & Daily Average Per Month & 1004 & 1064 & 991 & 619 & 805 & 659 & 633 & 827 & 603 & 874 & 875 & 864 & 818 \\
\hline
\end{tabular}

Figure 12: Bike Share Counts - Stations A, B, C, E, and L (2018 - 2019)

\begin{tabular}{|c|c|c|c|c|}
\hline Counter & Location & $\begin{array}{l}\text { Avg. } \\
\text { Daily Usage }\end{array}$ & Total Users & Page Number \\
\hline $\mathrm{H} 1$ & $\begin{array}{l}\text { Buffalo Bayou North Bank: St. Thomas High School } \\
\text { (Pedestrian Path) }\end{array}$ & 139 & 1,529 & 7 \\
\hline $\mathrm{H} 2$ & Buffalo Bayou North Bank: St. Thomas High School & $1,172 *$ & $7,032 *$ & 12 \\
\hline $\mathrm{H} 3$ & Buffalo Bayou South Bank: Lost Lake & 1,180 & 12,984 & 17 \\
\hline $\mathrm{H} 4$ & $\begin{array}{l}\text { Buffalo Bayou South Bank: Johnny Steele Dog Park } \\
\text { (Pedestrian Path) }\end{array}$ & $\mathrm{N} / \mathrm{A}^{* * *}$ & $\mathrm{~N} / \mathrm{A}^{* *}$ & 22 \\
\hline H5 & $\begin{array}{l}\text { Buffalo Bayou South Bank: Johnny Steele Dog Park } \\
\text { (Main Shared-Use Path) }\end{array}$ & 1,121 & 12,327 & 24 \\
\hline H6 & $\begin{array}{l}\text { Buffalo Bayou South Bank: Johnny Steele Dog Park } \\
\text { (Roadside Shared-Use Path) }\end{array}$ & 676 & 7,431 & 29 \\
\hline $\mathrm{H} 7$ & Buffalo Bayou North Bank: Green Tree Nature Area & 1,529 & 16,814 & 34 \\
\hline $\mathrm{T} 1$ & Buffalo Bayou North Bank: Police Memorial & 1,681 & 18,490 & 39 \\
\hline $\mathrm{T} 2$ & $\begin{array}{l}\text { Buffalo Bayou North Bank: Nature Play Area (Sabine } \\
\text { Street Access) }\end{array}$ & 966 & 10,626 & 44 \\
\hline $\mathrm{T} 3$ & $\begin{array}{l}\text { Buffalo Bayou North Bank: Nature Play Area (Main } \\
\text { Shared-Use Path) }\end{array}$ & 598 & 6,577 & 49 \\
\hline $\mathrm{T} 4$ & $\begin{array}{l}\text { Buffalo Bayou North Bank: Nature Play Area } \\
\text { (Pedestrian Path) }\end{array}$ & 380 & 4,183 & 54 \\
\hline $\mathrm{T} 5$ & Buffalo Bayou South Bank: Eleanor Tinsley Park & 1,539 & 16,924 & 59 \\
\hline $\mathrm{T} 7$ & Memorial Drive Westbound: West of Shepherd Drive & 133 & 1,462 & 64 \\
\hline T8 & Memorial Drive Eastbound: West of Shepherd Drive & 387 & 4,260 & 68 \\
\hline T9 & Memorial Drive Eastbound at East Terrace Drive & 171 & 1,882 & 72 \\
\hline $\mathrm{T} 10$ & Kirby Drive Southbound: West of Shepherd Drive & 237 & 2,608 & 76 \\
\hline $\mathrm{T} 11$ & Kirby Drive Northbound: West of Shepherd Drive & 64 & 705 & 80 \\
\hline $\mathrm{T} 12$ & $\begin{array}{l}\text { Shepherd Drive Southbound: South of Kirby } \\
\text { Drive/Allen Parkway }\end{array}$ & 104 & 1,149 & 84 \\
\hline $\mathrm{T} 13$ & $\begin{array}{l}\text { Shepherd Drive Northbound: South of Kirby } \\
\text { Drive/Allen Parkway }\end{array}$ & 88 & 963 & 88 \\
\hline $\mathrm{T} 14$ & Pedestrian/Bicycle Bridge at Shepherd Drive & 952 & 10,470 & 92 \\
\hline TOTAL & & 11,945 & 131,384 & \\
\hline
\end{tabular}

* The data is from September 30 to

October 10, 2016 Total user counts

$(131,384) / 11$ days $=$ Average daily

user counts

Figure 13: Pedestrian/Cyclist Counts (Houston-Galveston Area Council)

\section{Sources:}

BCycle. Station Maps. Accessed on June 11, 2019.

https://www.houstonbcycle.com/houston-bstations

Bike Count Data (Raw). BCycle Houston Bike Share, Development \& Communications. Henry Morris.

Bike Count Data. BikeBarn, Owner. Neil Brewner. 
Bike Count Data. EaDo, Owner. Nathan Marquez.

BikeBarn. Locations. Accessed on June 18, 2019.

https://www.bikebarn.com/about/buffalo-bayou-rentals-pg1892.htm

EaDo. Store Locator. Accessed on June 18, 2019.

https://www.eadobikeco.com/storelocator/

H-GAC, Pedestrian and Bicyclist Counters. Accessed June 6, 2019. http://www.hgac.com/pedestrian-bicyclist-planning/counters.aspx

\section{Limitations:}

Bike share data was provided by the respective companies and was not independently verified by the research team.

Since Bike Barn provided only annual data and EaDo provided data in six month periods, the daily averages were extrapolated by the research team.

Additionally, BCycle is a bike share program that provides a service for transportation and recreation while EaDo aims to provide a service for primarily recreation and athletic purposes. Bike Barn's service is a combination of these two approaches.

The pedestrian/cyclist data provided by the Houston-Galveston Area Council was from September and October of 2016. This data would be more accurate with a counting analysis having occurred more recently, however organizations and councils with these resources were not conducting this type of analysis at the time of this study. Additionally, the research team did not collect this data and therefore did not independently verify.

2. Provides additional and improved park access for over 21,000 housholds within a half-mile. Of these 38,000 residents, $8.1 \%$ live in poverty, $36 \%$ are minorities, and $5.8 \%$ are people with disabilities.

\section{Methods:}

Using a combination of American Community Survey (ACS) data and ESRI ArcGIS software, a $1 / 2$ mile buffer zone around the park periphery was defined. The smallest scale of geographic units was determined for the census block groups in order to analyze the population data within the buffer zone. Components of the population data were then extracted including residents living within the buffer zone neighborhoods in addition to a breakdown of vulnerable residents who are living in poverty, Hispanic, nonHispanic, disabled, elderly, without a personal car, and single parents.

\section{Calculations:}


A combination of ACS data and ESRI ArcGIS software was used to extract population data.

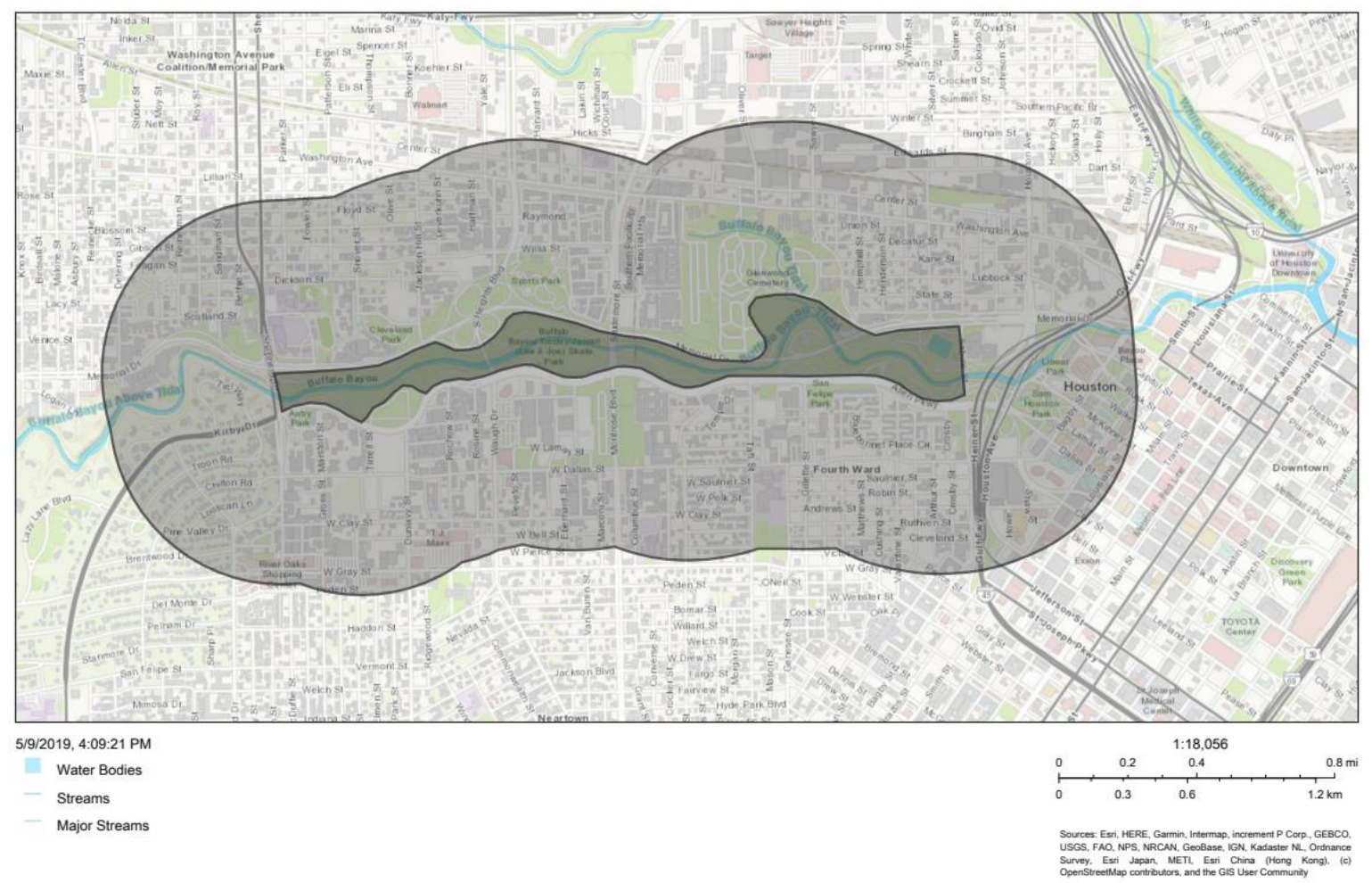

Figure 14: Buffalo Bayou Park $1 / 2$ Mile Buffer Zone (ESRI ArcGIS)

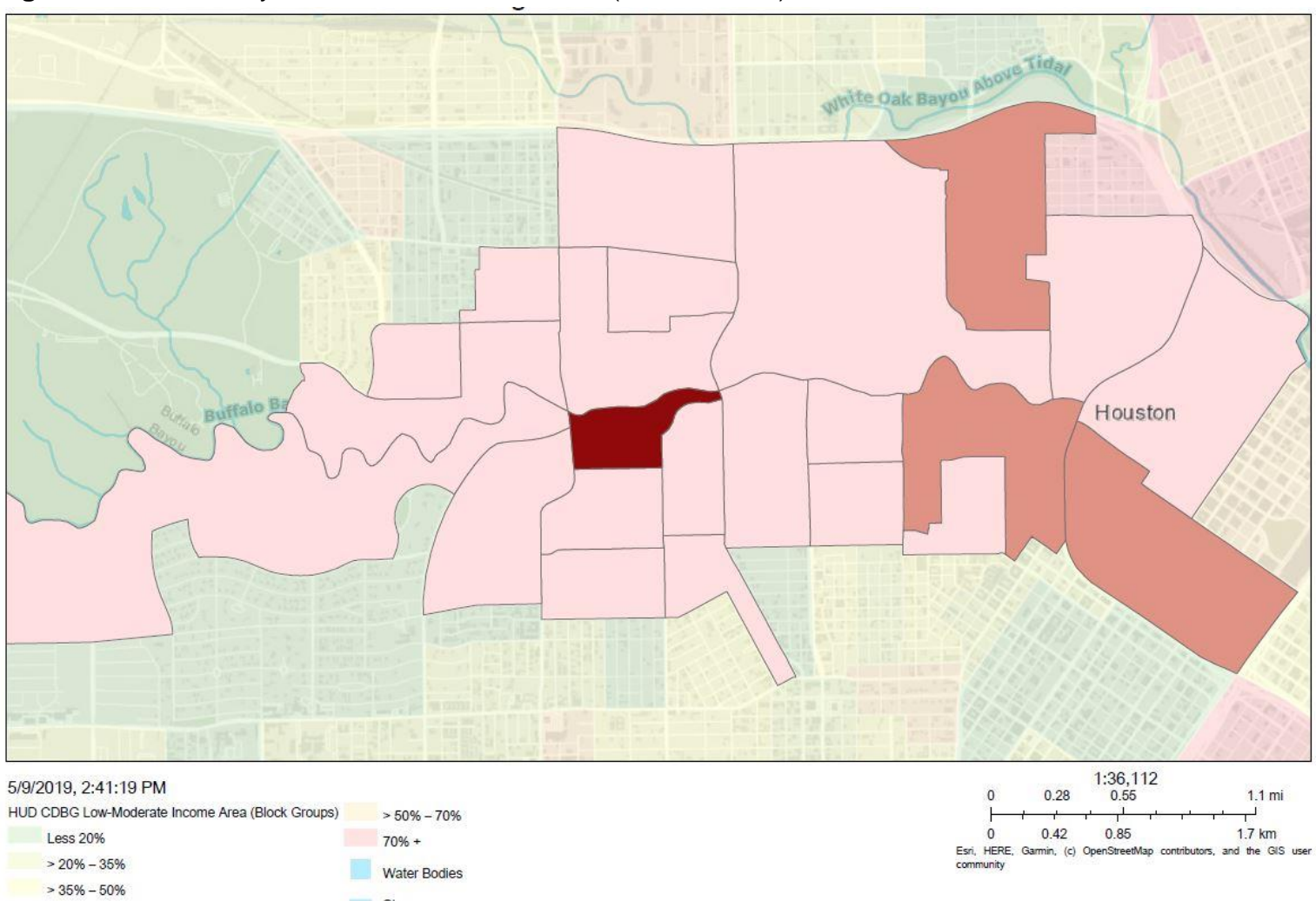


Figure 15: Buffalo Bayou Park Block Groups (ESRI ArcGIS)

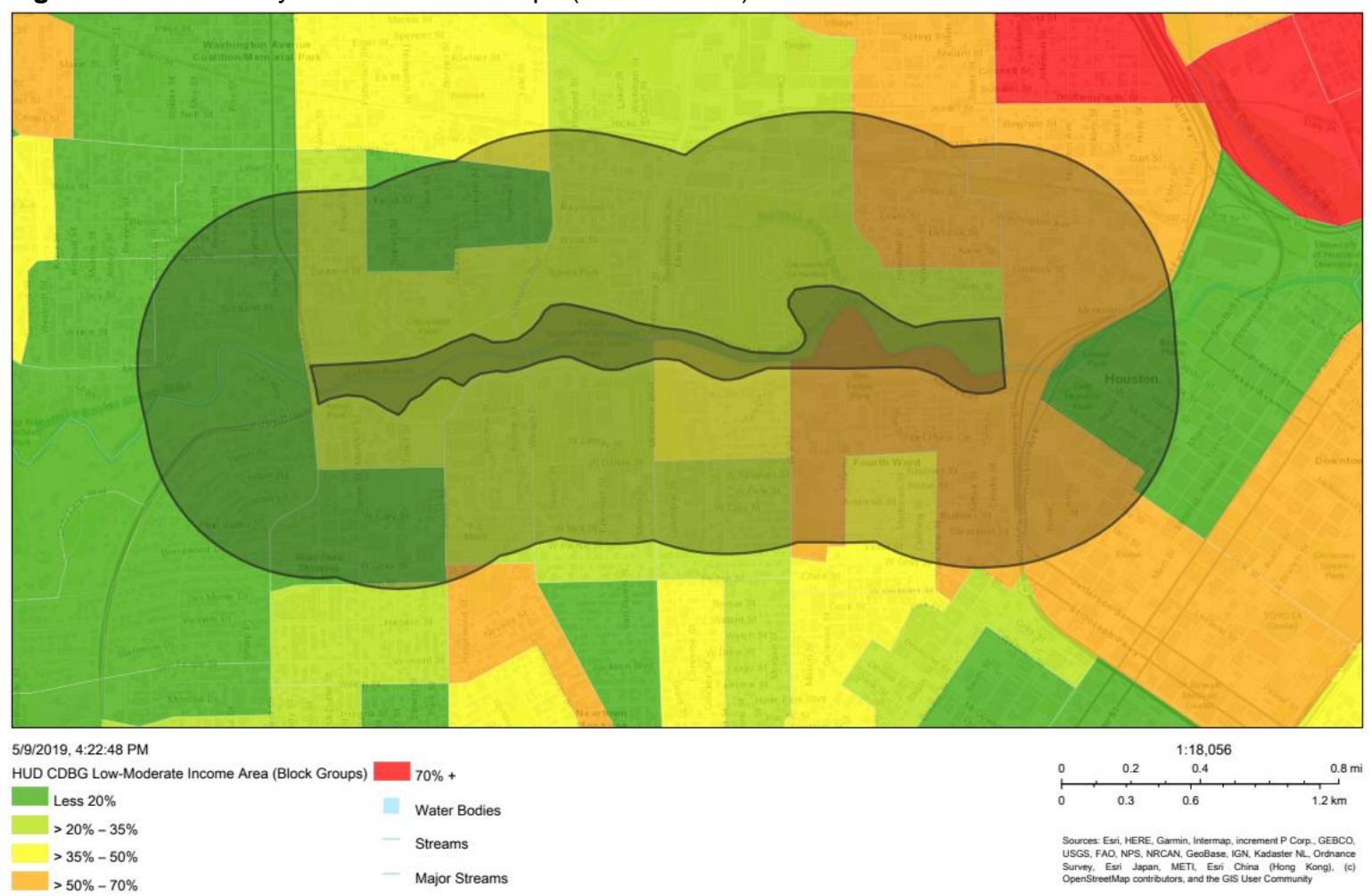

Figure 16: Buffalo Bayou Park Income Groups (ESRI ArcGIS)

$(3,150 \text { residents living in poverty/38,861 })^{*} 100=\mathbf{8 . 1} \%$

$(6,863 \text { Hispanic minorities } / 38,861)^{*} 100=\mathbf{1 7 . 7} \%$

$(7,130 \text { Non-Hispanic minorities/38,861 })^{*} 100=18.3 \%$

$17.7 \%+18.3 \%=36 \%$ total minorities

$(2,269$ residents with disabilities/38,861)* $100=5.8 \%$

$(1,274$ elderly residents $/ 38,861) * 100=3.3 \%$

(837 residents with no personal car/38,861)*100 $=2.2 \%$

(417 single parent households $/ 21,076)^{*} 100=2.0 \%$

Note: only full block groups that fit entirely within the half mile buffer were included in this analysis and the metadata provided the numbers within these block groups used in the calculations above.

\section{Sources:}

American Community Survey. 2017.

City of Houston GIS (COHGIS) parks data. Retrieved May 11, 2019 from https://cohgismycity.opendata.arcgis.com/

ESRI ArcGIS Tools for mapping and figures. 
Houston-Galveston Area Council (HGAC). Regional Data Lab. Regional Flood Information. Accessed on July 13, 2019: http://www.h-gac.com/interactive-webapplications/default.aspx

The Trust for Public Land. ParkScore Index. 2019. Accessed on July 13, 2019 from https://parkscore.tpl.org/evaluator/evaluator.html?city=Houston\&idx=38

\section{Limitations:}

The software collates and cross references many types of spatial datasets by location and is continuously updated. However, the software can sometimes inherit errors or inaccuracies every time a new dataset is imported which can skew results.

\section{Contributes to a self-reported decrease in physical ailments such as stress, asthma, and general poor health since beginning to come to the park according to $78 \%$ of 76 survey respondents who were repeat visitors.}

\section{Methods:}

A user survey was developed to assess the amenities and services preferred by people visiting the site and was offered in English and Spanish. The survey was administered on June 14, 2019 and June 15, 2019 from 9 am to $5 \mathrm{pm}$. The research team rotated between locations of frequent circulation and occupancy and asked visitors if they would be interested in taking a survey about the site and its amenities. Completed survey results were entered into a digital Qualtrics survey platform and were analyzed. The full survey can be found in Appendix A.

\section{Calculations:}

Question: Have you noticed a decrease in physical ailments such as, stress, asthma, and general poor health since you started coming to the park?

59 respondents answered "Yes"

$$
59 /(89-13)=59 / 76=.776 * 100=77.6 \%
$$

30 respondents answered "No"

13 respondents were first time visitors

89 total respondents

Self-reported first time visitors of the park $(\mathrm{N}=13)$ were eliminated from this analysis so that only repeat visitors were included to analyze this decrease.

\section{Sources:}

Survey Questions (refer to Appendix A)

Survey administration was conducted by the research team with additional administration provided by the Buffalo Bayou Partnership through social media outlets. 


\section{Limitations:}

The sample size was limited due to the number of hours the research team could spend on the site. The research team was aware of bias that can occur with convenience sampling. The team inquired with as many visitors as possible in order to obtain respondents for the survey. In order to supplement the total number of respondents obtained on site, the survey was also administered online and was sent to the general public and park employees through social media platforms and through email. This was accomplished with the help of the client, Buffalo Bayou Partnership.

\section{Contributes to improved quality of life and sense of well-being according to $90 \%$ of 89 survey respondents.}

\section{Methods:}

A user survey was developed to assess the amenities and services preferred by people visiting the site and was offered in English and Spanish. The survey was administered on June 14, 2019 and June 15, 2019 from 9 am to $5 \mathrm{pm}$. The research team rotated between locations of frequent circulation and occupancy and asked visitors if they would be interested in taking a survey about the site and its amenities. Completed survey results were entered into a digital Qualtrics survey platform and were analyzed. The full survey can be found in Appendix A.

\section{Calculations:}

Question: Could you rate the following statements regarding your experience with Buffalo Bayou Park?

80 respondents highly rated "Visiting the park improves my quality of life and sense of well-being."

$$
80 / 89=.899 * 100=89.9 \%
$$

72 respondents highly rated "Access to the park is easy."

$$
72 / 89=.809 * 100=80.9 \%
$$

77 respondents highly rated "The park provides diverse recreational activities."

$$
77 / 89=.865^{\star} 100=86.5 \%
$$

72 respondents highly rated "I feel safe and secure when I am in the park."

$$
72 / 89=.809 * 100=80.9 \%
$$

71 respondents highly rated "I can describe the park as a pleasant place to be overall."

$$
71 / 89=.798^{*} 100=79.8 \%
$$

41 respondents highly rated "I have an understanding of the cultural and historical importance of the park."

$$
41 / 89=.461^{*} 100=46.1 \%
$$

89 total respondents

\section{Sources:}


Survey Questions (refer to Appendix A)

Survey administration was conducted by the research team with additional

administration provided by the Buffalo Bayou Partnership through social media outlets.

\section{Limitations:}

The sample size was limited due to the number of hours the research team could spend on the site. The research team was aware of bias that can occur with convenience sampling. The team inquired with as many visitors as possible in order to obtain respondents for the survey. In order to supplement the total number of respondents obtained on site, the survey was also administered online and was sent to the general public and park employees through social media platforms and through email. This was accomplished with the help of the client, Buffalo Bayou Partnership.

5. Provides educational and cultural opportunities as demonstrated by the 30,000 people who attended Historic Cistern Tours in the park in 2018, a 58\% increase from 2016 attendance.

\section{Methods:}

Event data was provided by the Buffalo Bayou Partnership in order to calculate the increase in attendees for the Historic Cistern tour from 2016 to 2018.

\section{Calculations:}

Historic Cistern Tour

2018: 30,000 attendees

2017: 30,000 attendees

2016: 19,000 attendees

$30,000-19,000=11,000$

$(11,000 / 19,000)^{*} 100=\mathbf{5 7 . 8 9 \%}$

\section{Sources:}

Event data was provided by the Buffalo Bayou Partnership.

\section{Limitations:}

This data was not collected by the research team. 


\section{Helps to educate visitors about design solutions with $93 \%$ of 89 survey respondents able to identify at least one strategy to protect the bayou from flooding.}

\section{Methods:}

A user survey was developed to assess the amenities and services preferred by people visiting the site and was offered in English and Spanish. The survey was administered on June 14, 2019 and June 15, 2019 from 9 am to $5 \mathrm{pm}$. The research team rotated between locations of frequent circulation and occupancy and asked visitors if they would be interested in taking a survey about the site and its amenities. Completed survey results were entered into a digital Qualtrics survey platform and were analyzed. The full survey can be found in Appendix A.

\section{Calculations:}

Question: Which of the following would you consider the most effective potential solution to protecting the bayou from flooding? (You may choose up to four)

66 respondents answered "Local \& Native Plants"

$$
66 / 89=.742 * 100=74.2 \%
$$

34 respondents answered "Proper Maintenance"

$$
34 / 89=.382 * 100=38.2 \%
$$

29 respondents answered "Planted Bayou Banks"

$$
29 / 89=.326 * 100=32.6 \%
$$

28 respondents answered "Curve the Bayou"

$$
28 / 89=.315^{\star} 100=31.5 \%
$$

89 total respondents

$93 \%$ of respondents chose at least one correct answer (listed above). Only $7 \%$ of respondents chose incorrect answers including "Straighten the Bayou," "Concrete Bayou Banks," and "Non-Native Plants" or chose "Other/No Response".

Respondents were also asked about the educational activities they might have attended at the park regarding flood protection for the bayou and the park's resilient design. 20 participants responded that they have attended guided walking tours informing them about the bayou. Additionally, 27 respondents noted that they had also attended Cistern Tours and Boat Tours.

\section{Sources:}

Survey Questions (refer to Appendix A)

Survey administration was conducted by the research team with additional administration provided by the Buffalo Bayou Partnership through social media outlets.

\section{Limitations:}


The sample size was limited due to the number of hours the research team could spend on the site. The research team was aware of bias that can occur with convenience sampling. The team inquired with as many visitors as possible in order to obtain respondents for the survey. In order to supplement the total number of respondents obtained on site, the survey was also administered online and was sent to the general public and park employees through social media platforms and through email. This was accomplished with the help of the client, Buffalo Bayou Partnership.

\title{
7. Visually connects park users with downtown Houston as demonstrated by $45 \%$ of over 2,300 social media posts about the space referring to both the skyline and the park.
}

\author{
Methods: \\ A number of overlooks, viewing areas, plazas, pavilions, and seating areas exist \\ throughout the park in choreographed manner to allow visitors to engage with the bayou \\ (whereas previously, it was far less visually and physically accessible due to overgrown \\ vegetation) and to offer views across the park and toward the Houston skyline. Social \\ media was used to quantify the value of these views by cross-referencing the following \\ hashtags/tagged locations across various platforms. \\ Hashtags: \\ \#buffalobayoupark (500) \\ \#waughbridgebatcolony (100) \\ \#rosemontbridge (100) \\ \#jamailskatepark (100) \\ \#eleanortinsleypark (100) \\ \#policeofficersmemorial (100) \\ 1000 of the most recent posts for 6 hashtags/tagged locations (representing 5 of the \\ major overlooks and viewing areas within the park in addition to the primary Buffalo \\ Bayou Park hashtag) from 3 social media platforms were then visually reviewed for \\ photos that included the Houston skyline. This method was used for both Instagram and \\ Facebook. Due to the total quantity of available posts for Twitter being lower than the \\ other platforms, the number of analyzed posts was adjusted for each hashtag.
}

\section{Calculations:}

Park hashtags/tagged locations visually referencing the Houston skyline.

Instagram (Posts identified on June 11, 2019)

\#buffalobayoupark 209/500 =.418*100 = 41.8\% = 42\%

\#waughbridgebatcolony $9 / 100=.09^{*} 100=9 \%$ 
\#rosemontbridge 66/100 $=.66 * 100=66 \%$

\#jamailskatepark $25 / 100=.25^{\star} 100=25 \%$

\#eleanortinsleypark 61/100 $=.61 * 100=61 \%$

\#houstonpoliceofficersmemorial 61/100 $=.61 * 100=61 \%$

Average:

$(42 \%+9 \%+66 \%+25 \%+61 \%+61 \%) / 6=44 \%$

Facebook (Posts identified on June 13, 2019)

@ Buffalo Bayou Park 200/500 =.40*100 = 40\%

@ Waugh Bridge Bat Colony $24 / 100=.24 * 100=24 \%$

@ Rosemont Bridge 50/100 =.50*100 = 50\%

@ Jamail Skate Park 23/100 $=.23^{*} 100=23 \%$

@ Eleanor Tinsley Park 61/100 = .61*100 =61\%

Houston Police Officers Memorial N/A (removed from calculation)

Average:

$(40 \%+24 \%+50 \%+23 \%+61 \%) / 5=40 \%$

Twitter (Posts identified on June 19, 2019)

\#buffalobayoupark 168/300 = .560*100 = 56.\% = 56\%

\#waughbridgebatcolony $1 / 5=.20 * 100=20 \%$

\#rosemontbridge 10/13 = .769*100 = 77\%

\#jamailskatepark $7 / 24=.291 * 100=29 \%$

\#eleanortinsleypark 17/38 = .447*100 = 45\%

\#houstonpoliceofficersmemorial $7 / 9=.777^{*} 100=78 \%$

Average:

$(56 \%+20 \%+77 \%+29 \%+45 \%+78 \%) / 6=51 \%$

Total Average:

$(44 \%+40 \%+51 \%) / 3=45 \%$

\section{Sources:}

https://www.instagram.com/

https://www.facebook.com/

https://twitter.com/

\section{Limitations:}

Certain social media platforms allow users to share posts across platforms. This could have resulted in duplicate counts for posts. 
Social media posts that referenced multiple hashtags in a single post may have resulted in duplicate counts.

There is potential for human error in excluding photos not actually referencing the hashtags that were used for this calculation.

\section{Economic Benefits}

\section{Reduced turf maintenance costs by an estimated $54 \%$, saving $\$ 52,600$ annually in labor costs for mowing.}

\section{Methods:}

Previously a drainage corridor, the site had twice as much acreage of mown turf as the current park. Using data from the Maintenance Plan for Buffalo Bayou Park, the annual labor cost for mowing turf within the park was determined by multiplying the number of hours spent mowing on average by a market hourly rate for compensation provided. In addition, the annual labor costs for meadow and riparian zone cutbacks were determined as they comprise areas that were once mown turf prior to the park construction. Additional zones were listed below as well in order to note the full scope of planting and hardscape areas that replaced mown turf area. The annual labor cost method was then applied to the site pre-construction for comparison.

\section{Calculations:}

Buffalo Bayou Park

Turf: 1,676 hours annually for 38 acres (Maintenance Plan) $\$ 25 / \mathrm{hr}^{*} 1,676 \mathrm{hrs}=\$ 41,900 /$ year

Meadows: 124 hours annually for 15.2 acres (Maintenance Plan) $\$ 25 / h^{*} 124 \mathrm{hrs}=\$ 3,100 /$ year

Riparian: 38 hours annually for 4.8 acres (Maintenance Plan) $\$ 25 / \mathrm{hr}^{\star} 38$ hours $=\$ 950 /$ year

Native Woodland: 9.72 acres - no mowing

Cultured Woodland: 14.67 acres - no mowing

Hardscape: 7 acres - no mowing

\section{Total: \$45,950/year}

\section{Pre-Construction}

Turf: 3,943 hours annually for 89.4 acres (44.1 hours annually/acre extrapolated from Maintenance Plan) 
$\$ 25 / h r^{\star} 3,943 \mathrm{hrs}=\$ 98,575 /$ year

$98,575-45,950=52,625$

$(\$ 52,625 / \$ 98,575)^{\star} 100=53.39 \%$

\section{Sources:}

ETM Associates, LLC. Maintenance Plan for Buffalo Bayou Park: Post-Schematic Design. March 2012. Task and Budget Estimates

Additional mown turf data was provided by the landscape architect, SWA.

\section{Limitations:}

The annual hour data was not collected by the research team.

The Maintenance Plan references all components of maintenance for each of these planting categories. However, only the mowing maintenance costs for labor were calculated for this analysis, and many other benefits could be evaluated from the decrease in lawn area.

2. Contributed to a $13 \%$ average increase in the median property tax revenue for owner-occupied homes in the surrounding census tracts from 2013 to 2017, compared to a $7 \%$ increase for Harris County as a whole.

\section{Methods:}

The U.S. Census Bureau American Fact Finder was used to access census and American Community Survey data before and after the construction of the park from 2013 and 2017. The American Community Survey produces population, demographic, and housing unit estimates along with data on real estate taxes. For comparison, the five census tracts adjacent to the park were analyzed and compared to Harris County median data.

\section{Calculations:}

Property Taxes Census Tracts 4101, 4102, 4103, 5102, 5107:

Median dollars (2017): 3,633, 6,977, 5,844, 7,357, 8,099

Median dollars (2013): 4,277, 5,722, 5,354, 6,064, 6,433

Amount of Change: $-644,+1,255,+490,+1,293,+1,666$

Percent Change: $-15.06 \%,+21.93 \%,+9.15 \%,+21.32 \%,+25.90 \%$

Average: $(-15.06 \%+21.93 \%+9.15+21.32+25.90) / 5=12.65 \%$ 
Property Taxes in Harris County:

Median dollars (2017): 3,221

Median dollars (2013): 3,009

Amount of Change: +212

Percent Change: $7.05 \%$

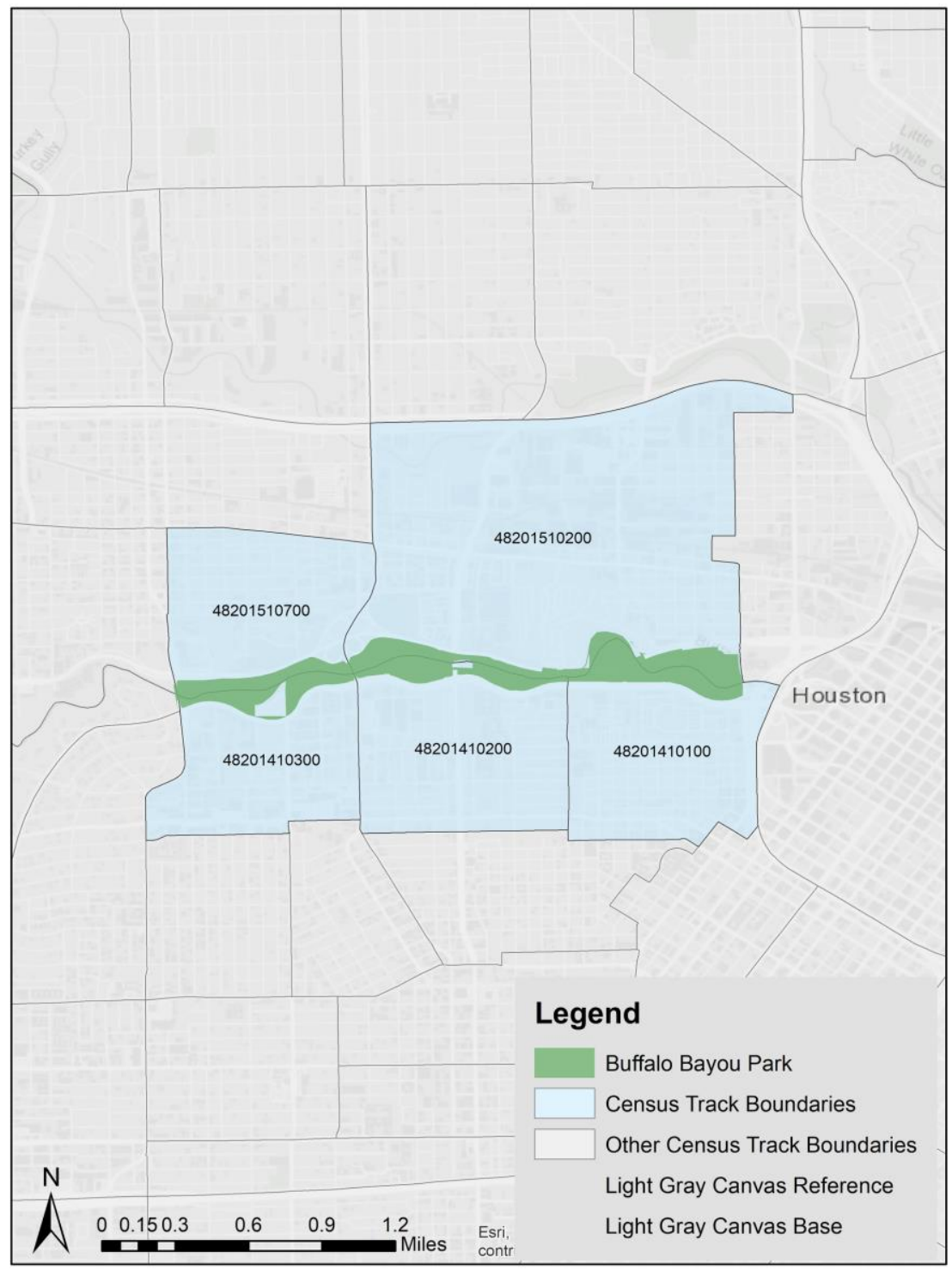

Figure 19: Census Tracts (ESRI ArcGIS) 


\begin{tabular}{|c|c|c|c|c|c|c|c|c|c|c|c|c|c|}
\hline & & \multicolumn{2}{|l|}{$\begin{array}{l}\text { Harris } \\
\text { County, } \\
\text { Texas }\end{array}$} & \multicolumn{2}{|c|}{$\begin{array}{l}\text { Census Tract 4101, } \\
\text { Harris County, Texas }\end{array}$} & \multicolumn{2}{|c|}{$\begin{array}{l}\text { Census Tract 4102, } \\
\text { Harris County, Texas }\end{array}$} & \multicolumn{2}{|c|}{$\begin{array}{l}\text { Census Tract } 4103 \text {, } \\
\text { Harris County, Texas }\end{array}$} & \multicolumn{2}{|c|}{$\begin{array}{l}\text { Census Tract 5102, } \\
\text { Harris County, Texas }\end{array}$} & \multicolumn{2}{|c|}{$\begin{array}{l}\text { Census Tract 5107, } \\
\text { Harris County, Texas }\end{array}$} \\
\hline & & Estimate & $\begin{array}{l}\text { Margin of } \\
\text { Error }\end{array}$ & Estimate & $\begin{array}{l}\text { Margin of } \\
\text { Error }\end{array}$ & Estimate & $\begin{array}{l}\text { Margin of } \\
\text { Error }\end{array}$ & Estimate & $\begin{array}{l}\text { Margin of } \\
\text { Error }\end{array}$ & Estimate & $\begin{array}{l}\text { Margin of } \\
\text { Error }\end{array}$ & Estimate & $\begin{array}{l}\text { Margin of } \\
\text { Error }\end{array}$ \\
\hline \multirow{3}{*}{2017} & $\begin{array}{l}\text { Median real estate taxes paid -- } \\
\text { Total: }\end{array}$ & 3,221 & $+1-23$ & 3,633 & $+/-1,806$ & 6,977 & $+\mid-793$ & 5,844 & $+\mid-922$ & 7,357 & $+/-1,005$ & 8,099 & $+\mid-424$ \\
\hline & $\begin{array}{l}\text { Median real estate taxes paid } \\
\text { for units with a mortgage }\end{array}$ & 3,619 & $+1-27$ & 3,800 & $+/-1,618$ & 7,983 & $+/-3,425$ & 5,211 & $+\mid-1,203$ & 7,337 & $+\mid-1,270$ & 8,127 & $+/-456$ \\
\hline & $\begin{array}{l}\text { Median real estate taxes paid } \\
\text { for units without a mortgage }\end{array}$ & 2,360 & $+/-37$ & & $*$ & 6,071 & $+1-702$ & 6,928 & $+\mid-1,405$ & 7,528 & $+/-4,172$ & 7,560 & $+/-1,961$ \\
\hline \multirow{6}{*}{2013} & Median real estate taxes paid -- & & & & & & & & & & & & \\
\hline & Total: & 3,009 & $+/-24$ & 4,277 & $+\mid-406$ & 5,722 & $+\mid-686$ & 5,354 & $+/-853$ & 6,064 & $+1-728$ & 6,433 & $+/-527$ \\
\hline & $\begin{array}{l}\text { Median real estate taxes paid } \\
\text { for units with a mortgage }\end{array}$ & 3,381 & $+/-26$ & 4,234 & $+/-546$ & 6,135 & $+/-765$ & 4,825 & $+/-1,016$ & 6,517 & $+/-658$ & 6,612 & $+/-545$ \\
\hline & $\begin{array}{l}\text { Median real estate taxes paid } \\
\text { for units without a mortgage }\end{array}$ & 2,113 & $+/-37$ & 4,500 & $+\mid-1,034$ & 4,222 & $+\mid-2,820$ & 7,065 & $+/-1,696$ & 1,656 & $+\mid-3,241$ & 2,559 & $+/-5,507$ \\
\hline & Amount of change & \multirow{2}{*}{\multicolumn{2}{|c|}{$\begin{array}{r}212 \\
7.05 \%\end{array}$}} & \multirow{2}{*}{\multicolumn{2}{|c|}{$\begin{array}{r}-644 \\
-15.06 \%\end{array}$}} & \multirow{2}{*}{\multicolumn{2}{|c|}{$\begin{array}{r}1,255 \\
21.93 \%\end{array}$}} & \multirow{2}{*}{\multicolumn{2}{|c|}{$\begin{array}{r}490 \\
9.15 \%\end{array}$}} & \multirow{2}{*}{\multicolumn{2}{|c|}{$\begin{array}{r}1,293 \\
2,32 \%\end{array}$}} & \multicolumn{2}{|l|}{1,666} \\
\hline & Percentage change & & & & & & & & & & & $25.90 \%$ & $12.64 \%$ \\
\hline
\end{tabular}

Figure 20: Calculations for Median Property Tax Revenue (United States Census Bureau)

\section{Sources:}

American Community Survey. United States Census Bureau - American Fact Finder. Accessed May 19th, 2018. https://factfinder.census.gov

\section{ESRI ArcGIS Mapping Tools}

United States Census Bureau - American Fact Finder. Accessed May 19, 2018.https://factfinder.census.gov

\section{Limitations:}

2017 was the most recent data available for median property tax revenue in the area. Additionally, many factors outside of the park can also contribute to these increases. The data used in this calculation is only collected for owner-occupied units.

\section{Catalyzed more than $\$ 2$ billion worth of investment within a 3-block radius of the park from 2013 to 2019.}

\section{Methods:}

Investment dollar amounts for completed and ongoing development projects adjacent to the park and known to the research team and the landscape architect were researched and collected from development companies. These projects all capitalize on the presence of the park through direct association with the park (developments containing Buffalo Bayou in their names, partnerships, etc.) and through promoting park adjacency, activities, and opportunities for residents and occupants through marketing material and websites.

\section{Calculations:}

The following investment data was collected from development companies: 
Buffalo Heights District (mixed use district)

Developer: Midway

$\$ 233$ million

The Allen (mixed use)

Developer: DC Partners

\$454 million

Broadstone Tinsley Park (residential)

Developer: Alliance Residential Company

$\$ 39.9$ million (land purchase only)

Regent Square

Developer: GID Development

$\$ 1.5$ billion

\section{Total: 2.3 billion}

Additional developments not releasing investment information at the time of this analysis:

Hanover Buffalo Bayou (mixed use)

Developer: The Hanover Company

Houston Endowment Offices

Ismaili Cultural Center - Aga Khan Foundation

Riva at the Park (residential)

Developer: Sims Luxury Builders

Park Place (office)

Developer: Pinto Partners

Jefferson Heights (residential)

Developer: JPI

LJB Apartments (residential)

Developer: LJB 

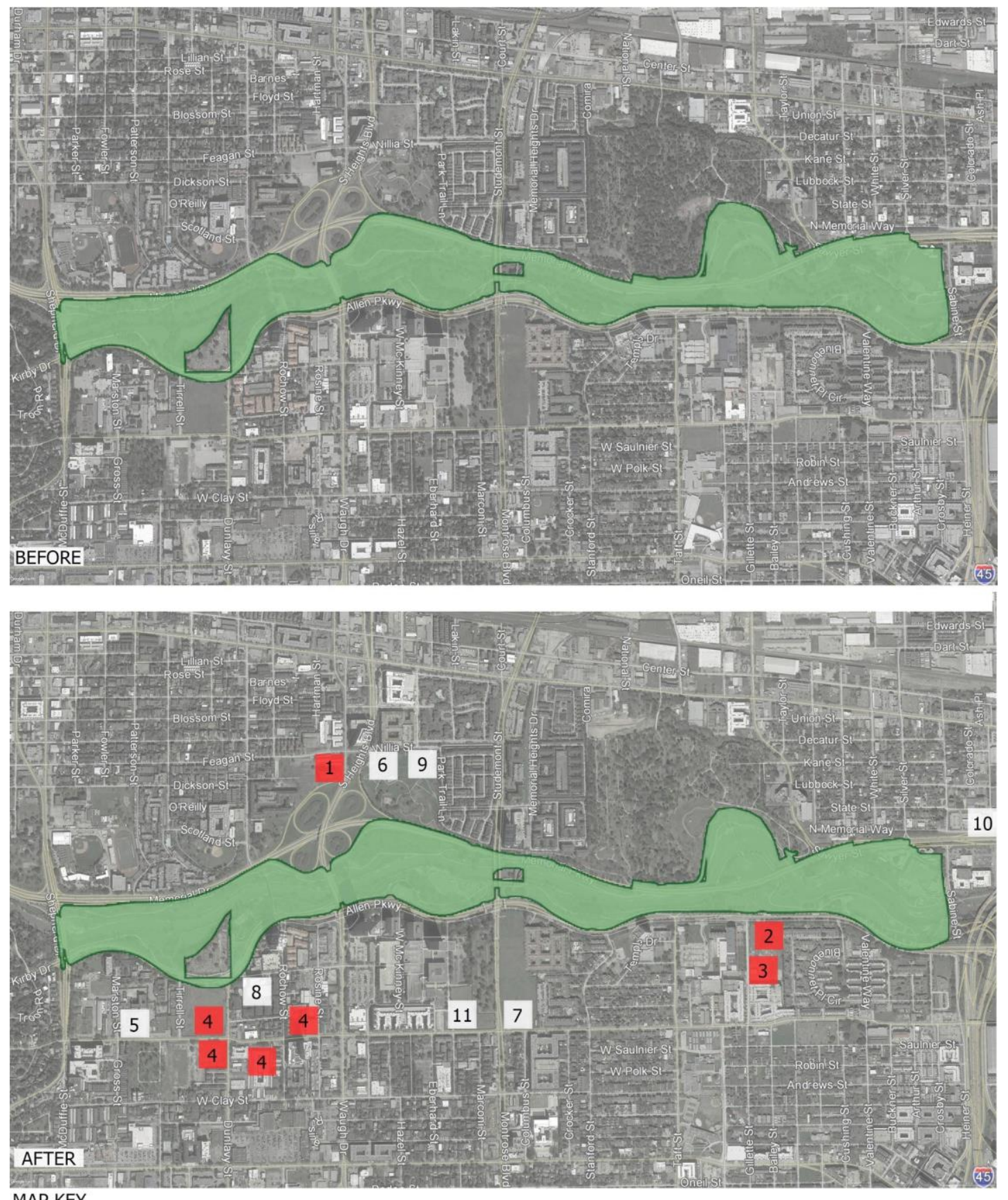

$\begin{array}{lll}\text { 1) Buffalo Heights District (mixed-use district) } & \text { 6) Houston Endowment Offices }\end{array}$

2) The Allen (mixed-use) $\quad$ 7) Ismaili Cultural Center (Aga Khan Foundation)

$\begin{array}{ll}\text { 3) Broadstone Tinsley Park (residential) } & \text { 8) Riva at the Park (residential) }\end{array}$

$\begin{array}{ll}\text { 4) Regent Square (mixed-use district) } & \text { 9) Park Place (office) }\end{array}$

$\begin{array}{ll}\text { 5) Hanover Buffalo Bayou (mixed-use) } & 10 \text { ) Jefferson Heights (residential) }\end{array}$

Figure 21: Adjacent park developments 2013 (before) - 2019 (after) 


\section{Sources:}

Chron, H-E-B "urban prototype". Accessed on June 5, 2019, https://www.chron.com/business/real-estate/article/H-E-B-urban-prototype-breaksground-near-11130544.php\#photo-12866645

"Construction and Development". GID. Accessed May 21, 2019. https://www.gid.com/our-capabilities/development/

DCpartners. Accessed May 21, 2019. http://dcpartnersusa.com/properties/the-allen/

GID, Construction and Development. Accessed on June 5, 2019, https://www.gid.com/our-capabilities/development/

Houston Architecture, Broadstone Tinsley Park. Accessed on June 6, 2019, https://www.houstonarchitecture.com/haif/topic/30184-broadstone-tinsley-park-byalliance-residential/

Houston Business Journal. \$500 million mixed-use development. Accessed on June 6, 2019. https://www.bizjournals.com/houston/news/2016/06/22/mixed-use-developmentslated-for-site-near-buffalo.html

Houston Business Journal. Long awaited phase of mixed-use project. Accessed on June 6, 2019. https://www.bizjournals.com/houston/news/2019/05/16/long-awaited-phase-ofmixed-use-project-near.html

Midway, 2018 Impact Report. Accessed on June 6, 2019. https://issuu.com/ midway2/docs/midway annual report web pages?e=28821381/68277785

Midway, Publications. Accessed on June 5, 2019. https://midwaycompanies.com/whowe-are/publications\#category=Publications

SWA-Surrounding \& Future Developments Document, 2019.

Yelp. Broadstone Tinsley Park. Accessed on June 5, 2019. https://www.yelp.com/biz/broadstone-tinsley-park-houston (Photo credits: User name: Sara M.)

\section{Limitations:}

This analysis includes as many development projects as were known to the research team, but there are a number of other development projects that are not included. Numerous developers with projects that have been announced and awarded were not releasing investment data at the time of this analysis and therefore could not be included. 
Additionally, developers of the included projects provided investment amounts, therefore they were not independently verified by the research team.

\section{COST COMPARISON}

A series of riparian bank stabilization techniques were considered during the design phase of Buffalo Bayou Park in order to control for bank erosion from fluctuating water levels throughout the course of each flood season. Where creating a 3:1 slope (or even a more conservative 4:1 slope) was not possible due to constrained right-of-way, the preferred method was to install gabion walls along the banks of the bayou in combination with a 2:1 slope of planting above to limit the amount of erosion during flood events. However, at $\$ 925.80$ per linear foot (If), installing gabion walls on both 2-mile-long banks was extremely cost-prohibitive. Instead, the design team stabilized the banks with vegetation at a 2:1 slope where wetland species would occupy the portion of the bank that would occasionally submerge, with a native grass mix above. Only a few locations were constructed with more aggressive stabilization techniques due to their high vulnerability for slope failure. Vegetated slope costs were $\$ 72.50$ per If, most of which was already included in the planting budget.

However, due to the known vulnerable nature of vegetated slopes without gabion walls, repairs were necessary after Hurricane Harvey. The cost of repair for 4,315 If of slope failures at $\$ 748.50$ per If was $\$ 3,229,778$. If this same linear footage of banks had been initially constructed with gabion walls, that cost would have been $\$ 3,994,827$. While the repair costs for these vegetated slope failures totaled less than the cost to construct gabion walls in these locations, repetitive failures from future flooding events will cause this gap to shrink.

\section{Methods:}

Each stabilization method was priced per linear foot by the landscape architect and HCFCD in order to determine the best method for the project budget.

\section{Calculations:}

Each stabilization method was determined in the chart below. Additionally, the repair costs for the selected stabilization method from Hurricane Harvey were determined as well. 
Buffalo Bayou Slope Stabilization Costs

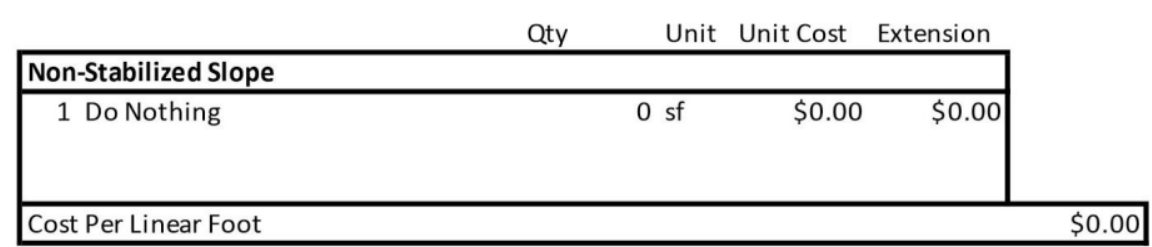

\begin{tabular}{|c|c|c|c|}
\hline Lay Back Slope to 4:1 & & & \\
\hline 1 Excavation & $33.33 \mathrm{cy}$ & $\$ 10.00$ & $\$ 333.30$ \\
\hline 2 Sod & $124 \mathrm{sf}$ & $\$ 0.50$ & $\$ 62.00$ \\
\hline Cost Per Linear Foot & & & \\
\hline
\end{tabular}

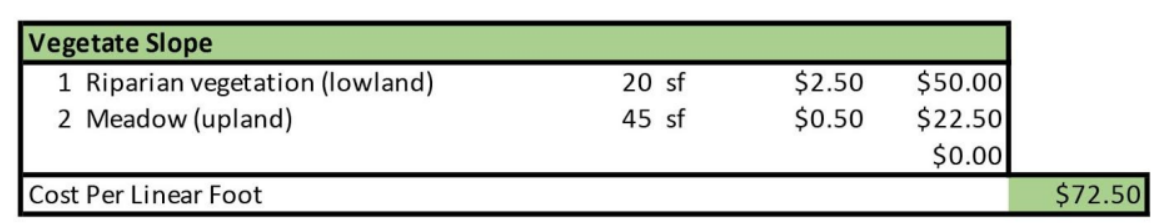

\begin{tabular}{|lrrrr|}
\hline Buried Riprap (Stabilization and/or Repair) & & & \\
\cline { 1 - 4 } 1 Riprap & $5.6 \mathrm{cy}$ & $\$ 100.00$ & $\$ 560.00$ \\
2 Soil & $4.5 \mathrm{cy}$ & $\$ 35.00$ & $\$ 157.50$ \\
3 Sod & $62 \mathrm{sf}$ & $\$ 0.50$ & $\$ 31.00$ & \\
\hline Cost Per Linear Foot & & & & $\$ 748.50$ \\
\hline
\end{tabular}

\begin{tabular}{|c|c|c|c|}
\hline \multicolumn{4}{|l|}{ Coir Lifts } \\
\hline 1 Riprap & $1.5 \mathrm{cy}$ & $\$ 100.00$ & $\$ 150.00$ \\
\hline 2 Granular Fill & $1.8 \mathrm{cy}$ & $\$ 166.00$ & $\$ 298.80$ \\
\hline 3 Toewood & 1 If & $\$ 150.00$ & $\$ 150.00$ \\
\hline 4 Coir Fabric & 20 sy & $\$ 1.00$ & $\$ 20.00$ \\
\hline 5 Imported Fill for Coir Lifts & $4 \mathrm{cy}$ & $\$ 40.00$ & $\$ 160.00$ \\
\hline 6 Coir Fiber Geogrid & 1 If & $\$ 30.00$ & $\$ 30.00$ \\
\hline 7 Live Stakes & 18 ea & $\$ 2.00$ & $\$ 36.00$ \\
\hline 8 Meadow (upland) & $40 \mathrm{sf}$ & $\$ 0.50$ & $\$ 20.00$ \\
\hline Cost Per Linear Foot & & & \\
\hline
\end{tabular}

\begin{tabular}{|lrrrr|}
\hline Gabions & & & \\
\hline 1 Gabion & $2.7 \mathrm{cy}$ & $\$ 324.00$ & $\$ 874.80$ \\
2 Riparian vegetation (lowland) & $11 \mathrm{sf}$ & $\$ 2.50$ & $\$ 27.50$ \\
3 Meadow (upland) & $47 \mathrm{sf}$ & $\$ 0.50$ & $\$ 23.50$ & \\
\hline Cost Per Linear Foot & & & & $\$ 925.80$ \\
\hline
\end{tabular}

\begin{tabular}{|llrrr|}
\hline Sheet Pile Wall & & & & \\
\hline 1 Sheet Pile Wall & $25 \mathrm{sff}$ & $\$ 40.00$ & $\$ 1,000.00$ \\
2 Concrete Cap & $0.148 \mathrm{cy}$ & $\$ 1,500.00$ & $\$ 222.00$ \\
3 Meadow (upland) & $47 \mathrm{sf}$ & $\$ 0.50$ & $\$ 23.50$ \\
\hline
\end{tabular}

Cost Per Linear Foot

Notes:

Construction cost only; does not include soft costs, design fees, contractor Does not include Right-of-Way acquisition

Figure 22: Stabilization Technique Cost Comparison, SWA 
Site:

2.3 miles long (12,144 If)

2 banks (north and south)

12,144 If ${ }^{\star}=24,288$ If

Vegetated Slopes:

$\$ 72.50 /$ If

$\$ 72.50 /$ If $^{\star} 24,288$ If $=\$ 1,760,880.00$

Gabion Walls:

$\$ 925.80 / \mathrm{lf}$

$\$ 925.80 / I^{\star} 24,288$ If $=\$ 22,485,830.40$

Cost of Vegetated Slope Repair:

$\$ 748.50 /$ If

Length of slopes in need of repair: 4,315 If (repair location data provided by the Harris County Flood Control District)

$\$ 748.50 /$ If $^{*} 4,315$ If $=\$ \mathbf{3 , 2 2 9 , 7 7 8}$

Cost of Same Linear Footage Having Been Constructed of Gabion Walls Initially: $\$ 925.80 /$ lf

$\$ 925.80 /$ If $^{\star} 4,315$ If $=\$ 3,994,827$

Repair Location

Bank

South

North

North

South

North

South

South

Buried Riprap: Cost per LF $\$ 748.50$

Gabion: Cost per LF $\$ 925.80$

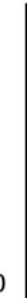

\begin{tabular}{|r|rr}
\hline LF & Repair Cost/LF & Exten \\
70 & $\$ 748.50$ \\
200 & $\$ 748.50$ \\
1,575 & $\$ 748.50$ \\
850 & $\$ 748.50$ \\
520 & $\$ 748.50$ \\
800 & $\$ 748.50$ \\
300 & $\$ 748.50$ \\
\hline 4,315 & & \\
\hline
\end{tabular}

xtens

\begin{tabular}{r|rr|}
\multicolumn{1}{|l|}{ nsion } & Gabion Cost/LF & \multicolumn{1}{|c|}{ Extension } \\
$\$ 52,395$ & $\$ 925.80$ & $\$ 64,806$ \\
$\$ 149,700$ & $\$ 925.80$ & $\$ 185,160$ \\
$\$ 1,178,888$ & $\$ 925.80$ & $\$ 1,458,135$ \\
$\$ 636,225$ & $\$ 925.80$ & $\$ 786,930$ \\
$\$ 389,220$ & $\$ 925.80$ & $\$ 481,416$ \\
$\$ 598,800$ & $\$ 925.80$ & $\$ 740,640$ \\
$\$ 224,550$ & $\$ 925.80$ & $\$ 277,740$ \\
\hline$\$ 3,229,778$ & & $\$ 3,994,827$ \\
\hline
\end{tabular}

Figure 23: Slope Repairs - Vegetated Slopes (repaired with Buried Riprap) v. Initial Gabion Wall Construction for the Same Linear Footage 


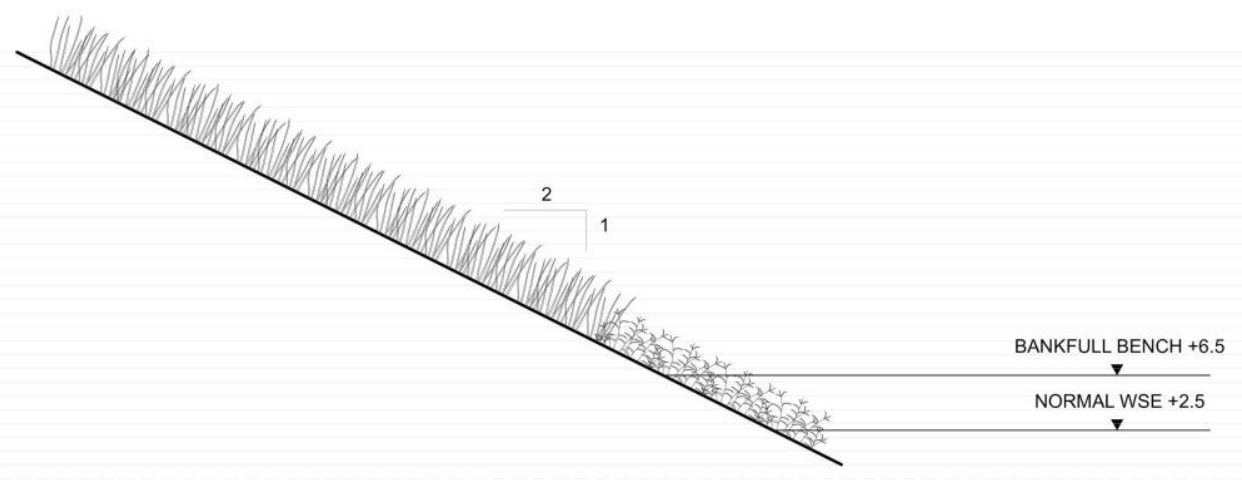

VEGETATED SLOPE

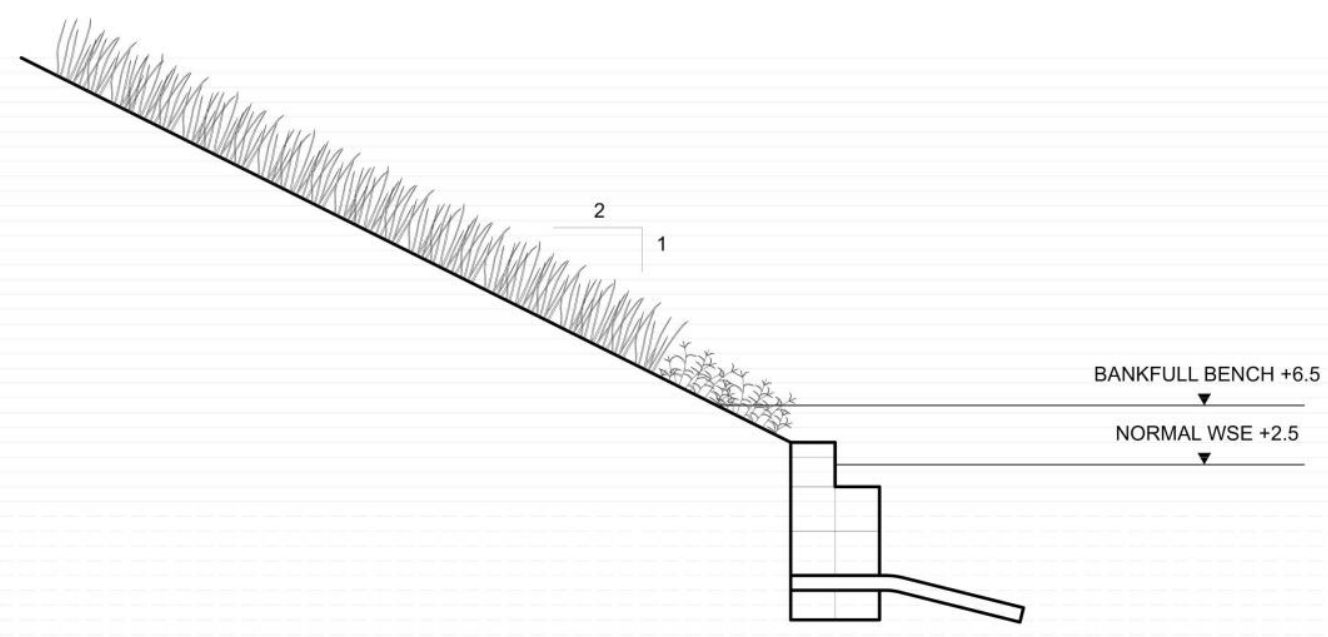

GABIONS

Figure 24: Stabilization Techniques - Vegetated Slope v. Gabion Walls 


\section{Sources:}

Stabilization data was provided by the landscape architect, SWA, and the Harris County Flood Control District (HCFCD).

\section{Limitations:}

The costs determined for each stabilization technique are for construction costs only as they do not include soft costs, design fees, or contractor overhead.

High-level cost data was provided by the Harris County Flood Control District, however the research team extrapolated this data in order to determine some of the itemized criteria for this analysis.

Additionally, where certain banks do not meet the slope criteria for these techniques and exist in close proximity to property lines and Right-of-Way boundaries, their slopes and/or Right-of-Way boundaries needed to be adjusted or acquired. The costs determined here do not take into account Right-of-Way acquisition for those conditions.

\section{INCONCLUSIVE BENEFIT}

\section{Contributed to a $68 \%$ average increase in assessed property value for 47 randomly selected parcels within a half-mile of the park from 2013 to 2019 and a $13 \%$ increase for parcels within a one-block radius from 2013 to 2019. For 62 randomly selected properties across the zip code area, the average increase was just $26 \%$.}

\footnotetext{
Methods:

Analysis was performed on 47 randomly selected units/parcels within a half-mile radius, in addition to 18 randomly selected units/parcels within a one-block radius, in order to understand the impact the park has made on neighboring property values. Unit and parcel data for property values within a specified period of time was obtained from the Harris County Appraisal District (HCAD) interactive map tool. Before finalizing the selection of units/parcels, data that was not accurately extracted or still pending was removed. The percentage increase in property value for each unit/parcel was calculated, upper and lower outliers were removed, and then the average for these units/parcels was used as a final estimate for the increase in property values from 2013 (before the park was constructed) to 2019 (current).

Overall, results did not indicate an increase in property value for properties within a halfmile and one block of the park strongly enough to attribute increases to the park,
} 
although it could be assumed that this is likely the case. This benefit would require further study to verify the economic benefit.

\section{Calculations:}

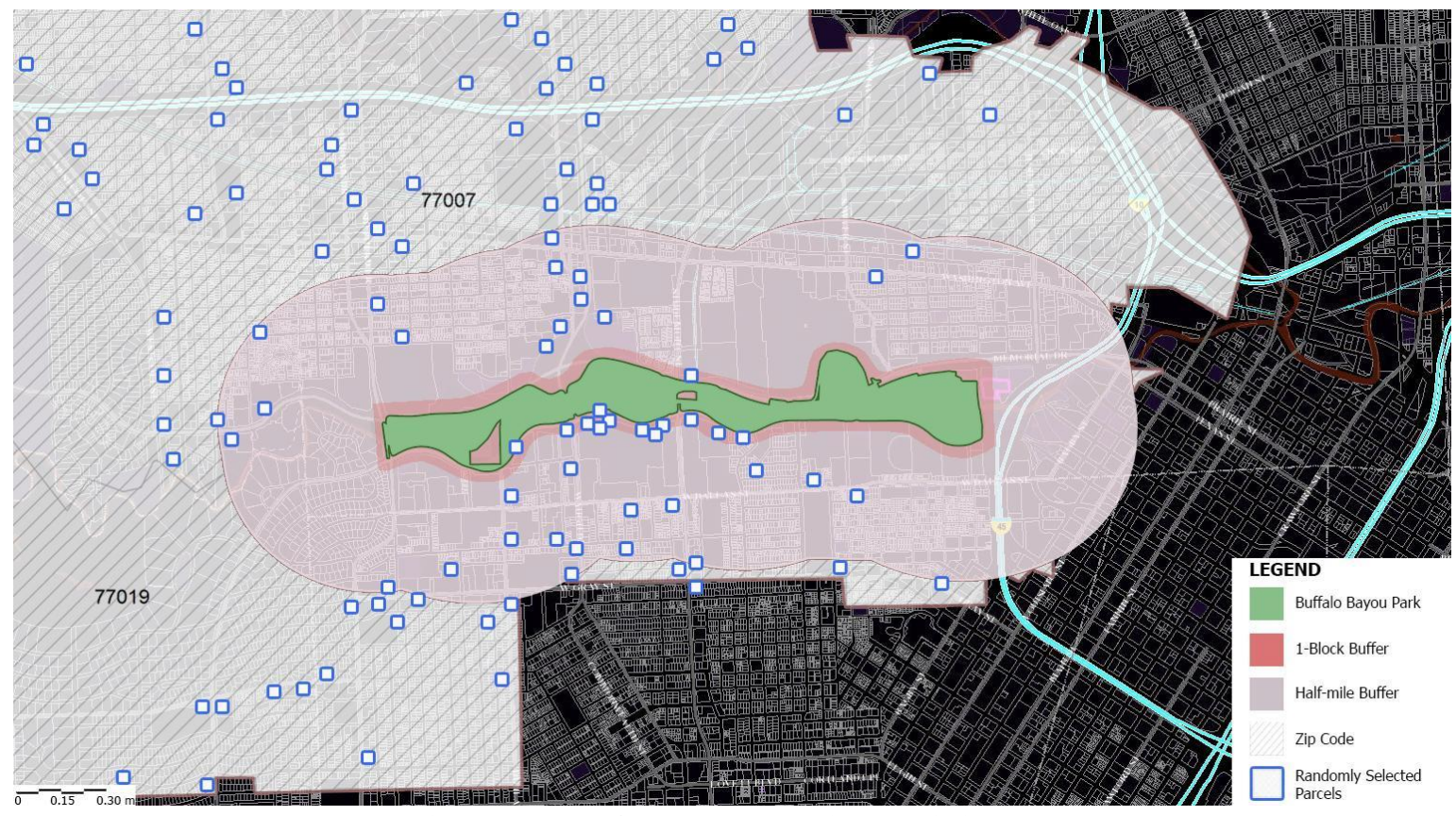

Figure 17: Buffalo Bayou Park Selected Units/Parcels Map (ESRI ArcGIS)

Two geographic scales were used to analyze property values (half-mile radius and oneblock radius). The property values for the selected units/parcels were extracted from the Harris County Appraisal District between 2013 and 2019. The change in property values for each unit/parcel was converted to a percentage and listed in the table below. These percentages were then averaged to obtain the average increase in property value.

Of the 47 randomly selected parcels within a half-mile buffer, 34 parcels gained value with an average increase in value of $88 \%$ (calculated only for those that gained value except for 1 parcel as it was an outlier). Of the 18 randomly selected parcels within a one-block radius, 10 parcels gained value with an average increase in value of $106 \%$ (calculated only for those that gained value except for 1 parcel as it was an outlier). This was compared to the 62 randomly selected parcels within the same zip code where 37 parcels gained value with an average increase in value of $48 \%$ (calculated only for those that gained value except for 1 parcel as it was an outlier). 


\begin{tabular}{|r|r|}
\hline HALF MILE BUFFER & 1-BLOCK BUFFER \\
\hline$-6.83 \%$ & $102.18 \%$ \\
\hline $244.99 \%$ & $0.00 \%$ \\
\hline $404.94 \%$ & $-3.65 \%$ \\
\hline$-45.48 \%$ & $15.03 \%$ \\
\hline$-15.07 \%$ & $-24.45 \%$ \\
\hline $359.10 \%$ & $-21.27 \%$ \\
\hline $167.00 \%$ & $11.44 \%$ \\
\hline $183.54 \%$ & $121.40 \%$ \\
\hline $29.19 \%$ & $1553.21 \%$ \\
\hline $7.89 \%$ & $62.74 \%$ \\
\hline $5.89 \%$ & $46.41 \%$ \\
\hline $117.84 \%$ & $176.80 \%$ \\
\hline $54.56 \%$ & $-1.41 \%$ \\
\hline $20.77 \%$ & $-20.55 \%$ \\
\hline $0.71 \%$ & $-31.13 \%$ \\
\hline $46.12 \%$ & $366.07 \%$ \\
\hline $7.95 \%$ & $53.78 \%$ \\
\hline$-31.49 \%$ & $-44.67 \%$ \\
\hline $17.81 \%$ & \\
\hline$-60.46 \%$ & \\
\hline $22.18 \%$ & \\
\hline $105.83 \%$ & \\
\hline $151.01 \%$ & \\
\hline$-38.70 \%$ & \\
\hline$-12.90 \%$ & \\
\hline$-5.42 \%$ & \\
\hline$-9.85 \%$ & \\
\hline$-78.24 \%$ & \\
\hline$-32.72 \%$ & \\
\hline $88.38 \%$ & \\
\hline$-9.13 \%$ & \\
\hline $639.02 \%$ & \\
\hline $228.86 \%$ & \\
\hline $18.59 \%$ & \\
\hline$-13.56 \%$ & \\
\hline $31.15 \%$ & \\
\hline $11.23 \%$ & \\
\hline $1.17 \%$ & \\
\hline $39.36 \%$ & \\
\hline $162.06 \%$ & \\
\hline $131.48 \%$ & \\
\hline $4.67 \%$ & \\
\hline $78.76 \%$ & \\
\hline $6.69 \%$ & \\
\hline & \\
\hline & \\
\hline & \\
\hline & \\
\hline & \\
\hline & \\
\hline & \\
\hline & \\
\hline & \\
\hline & \\
\hline & \\
\hline & \\
\hline & \\
\hline & \\
\hline & \\
\hline & \\
\hline & \\
\hline & \\
\hline & \\
\hline & \\
\hline & \\
\hline & \\
\hline & \\
\hline & \\
\hline & \\
\hline & \\
\hline
\end{tabular}

\begin{tabular}{|l|l|}
\hline $67.97 \%$ & $131.22 \%$ \\
\hline
\end{tabular}

Figure 18: Buffalo Bayou Park Selected Units/Parcels Data (Harris County Appraisal District) 


\section{Sources:}

Harris County Appraisal District., Property Search. Accessed on May 24, 2019

http://hcad.org/property-search/business-personal-mineral/

ESRI ArcGIS Tools for mapping and figures.

\section{Limitations:}

County level appraisal data was used for these calculations, therefore the accuracy of the data is dependent on the property value sources which the research team did not independently verify.

As a note, the unit/parcel locations were obtained from Google Maps and Google Earth and were enlarged in the maps for illustrative purposes. 
Appendix A

Survey Results

\section{Q1 - Are you a:}

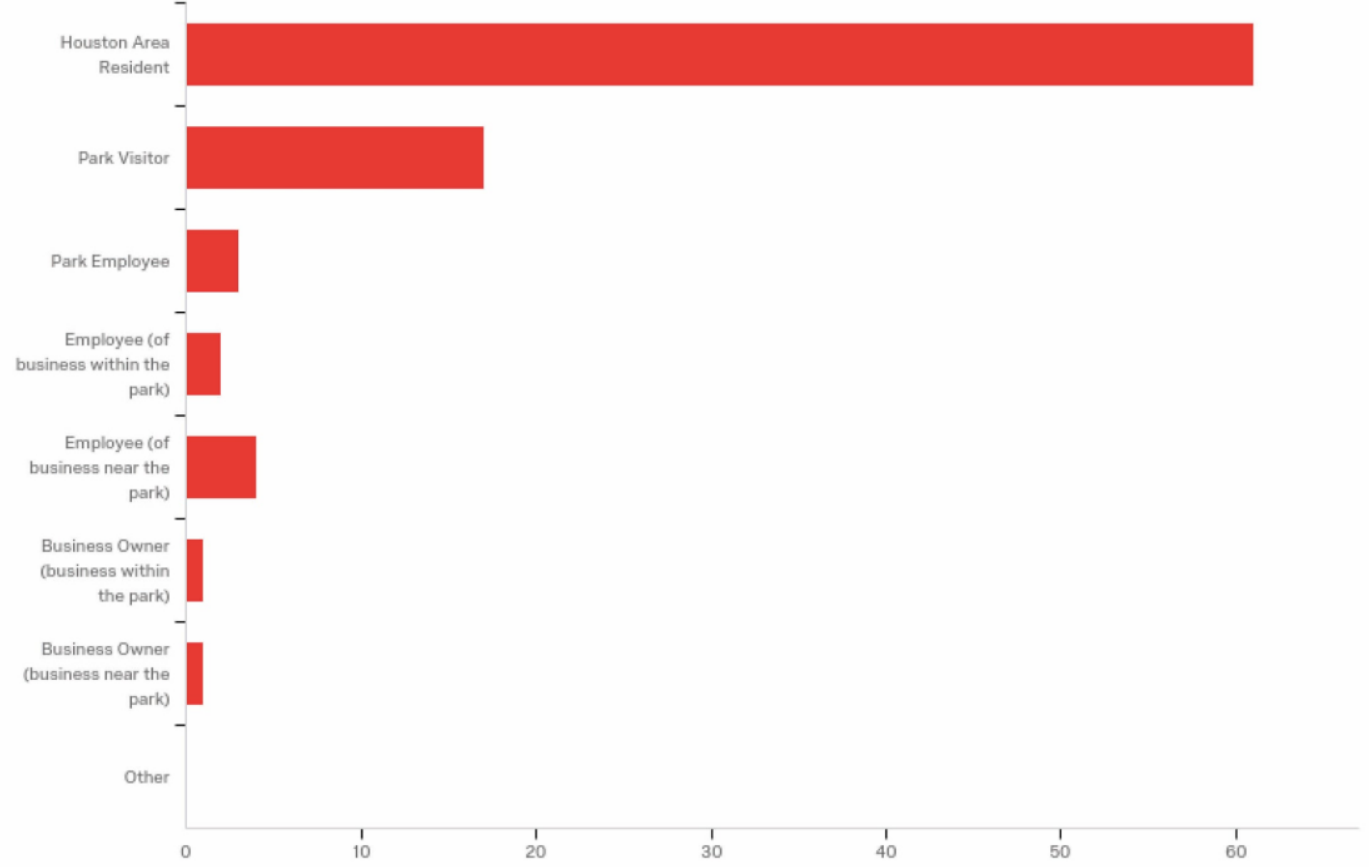


Q2 - Approximately how often do you typically visit the park?

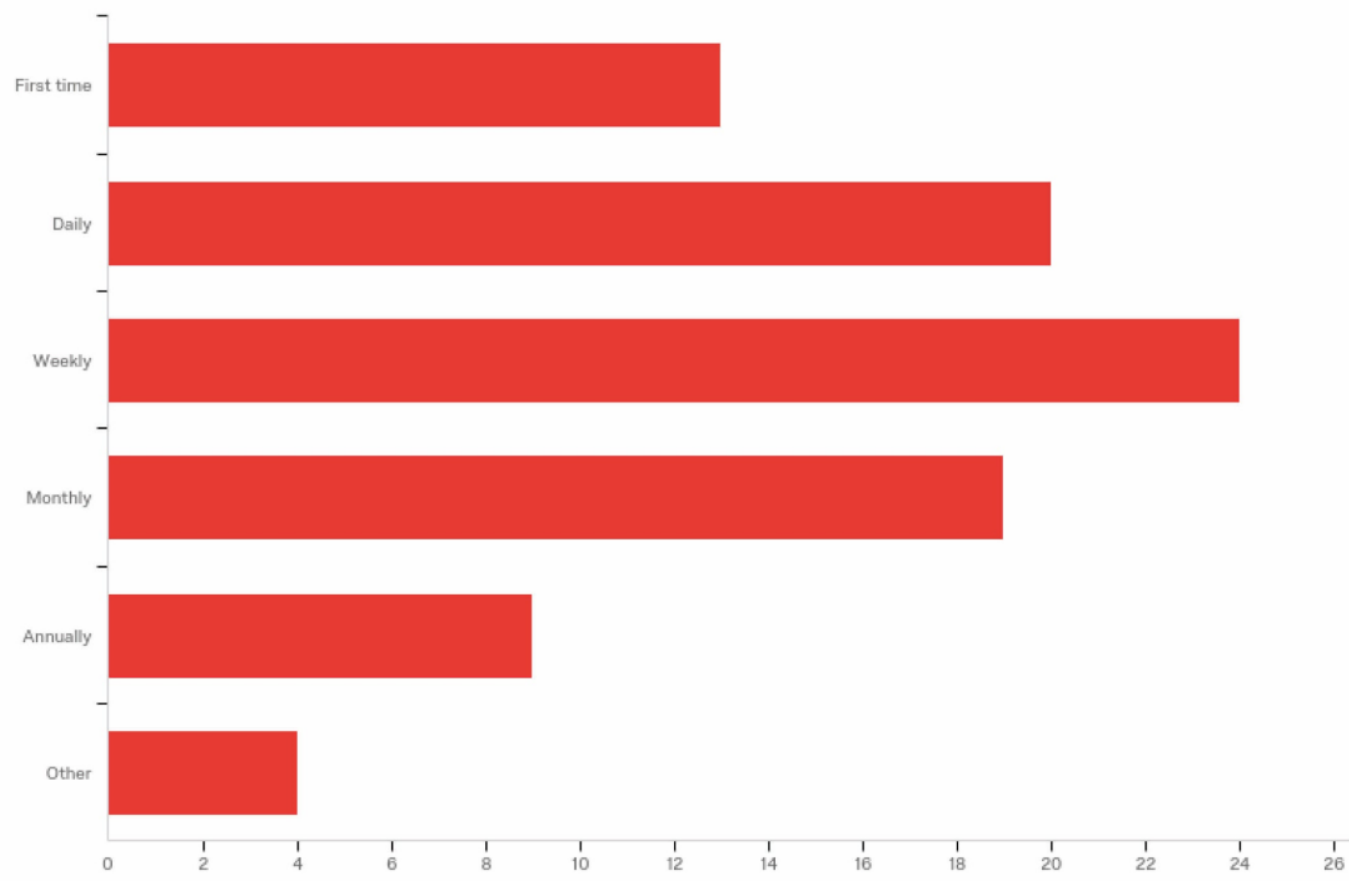


Q3 - What time of day do you typically visit the park?

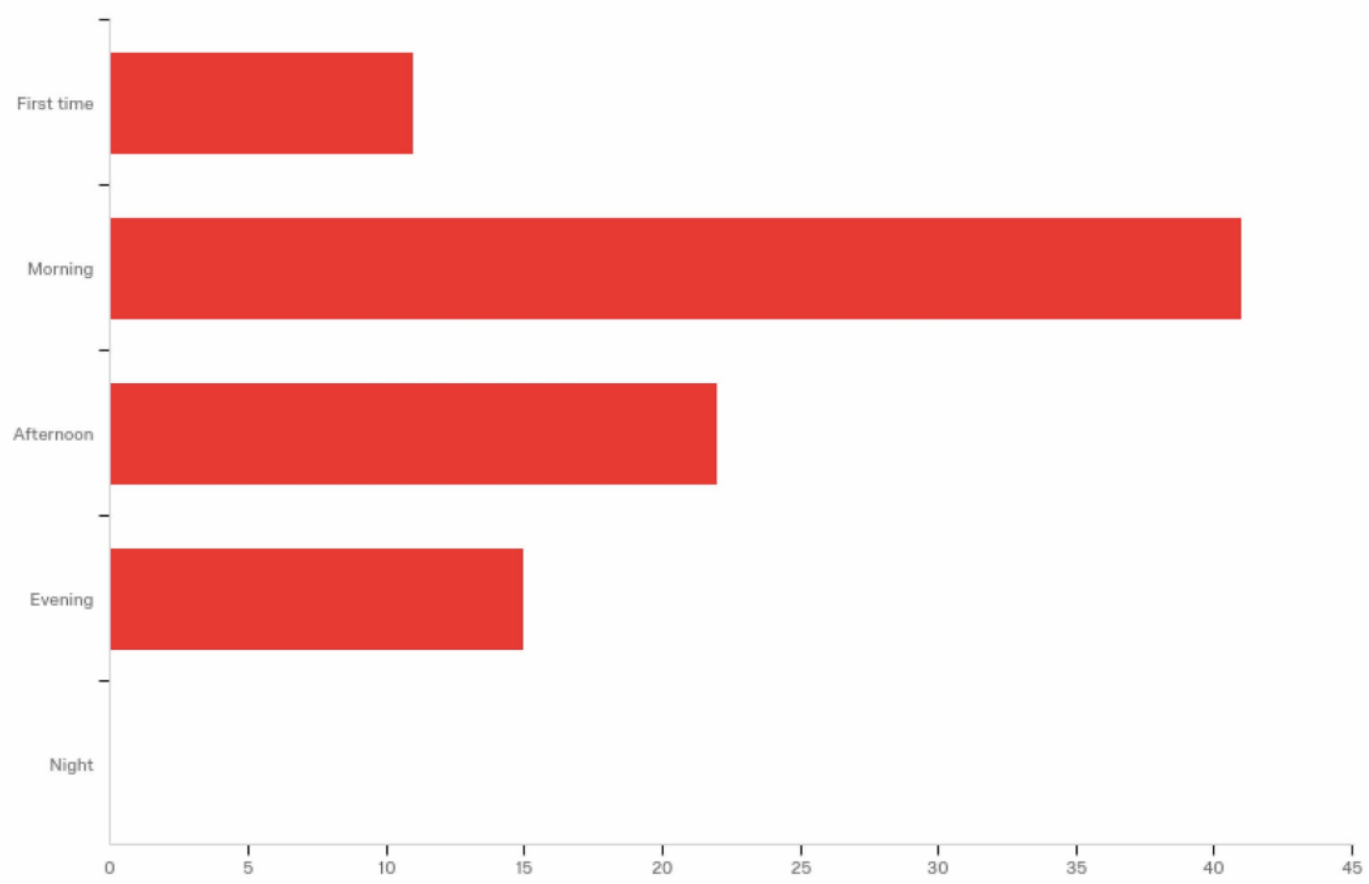


Q4 - What park elements do you most often use/visit at the park?

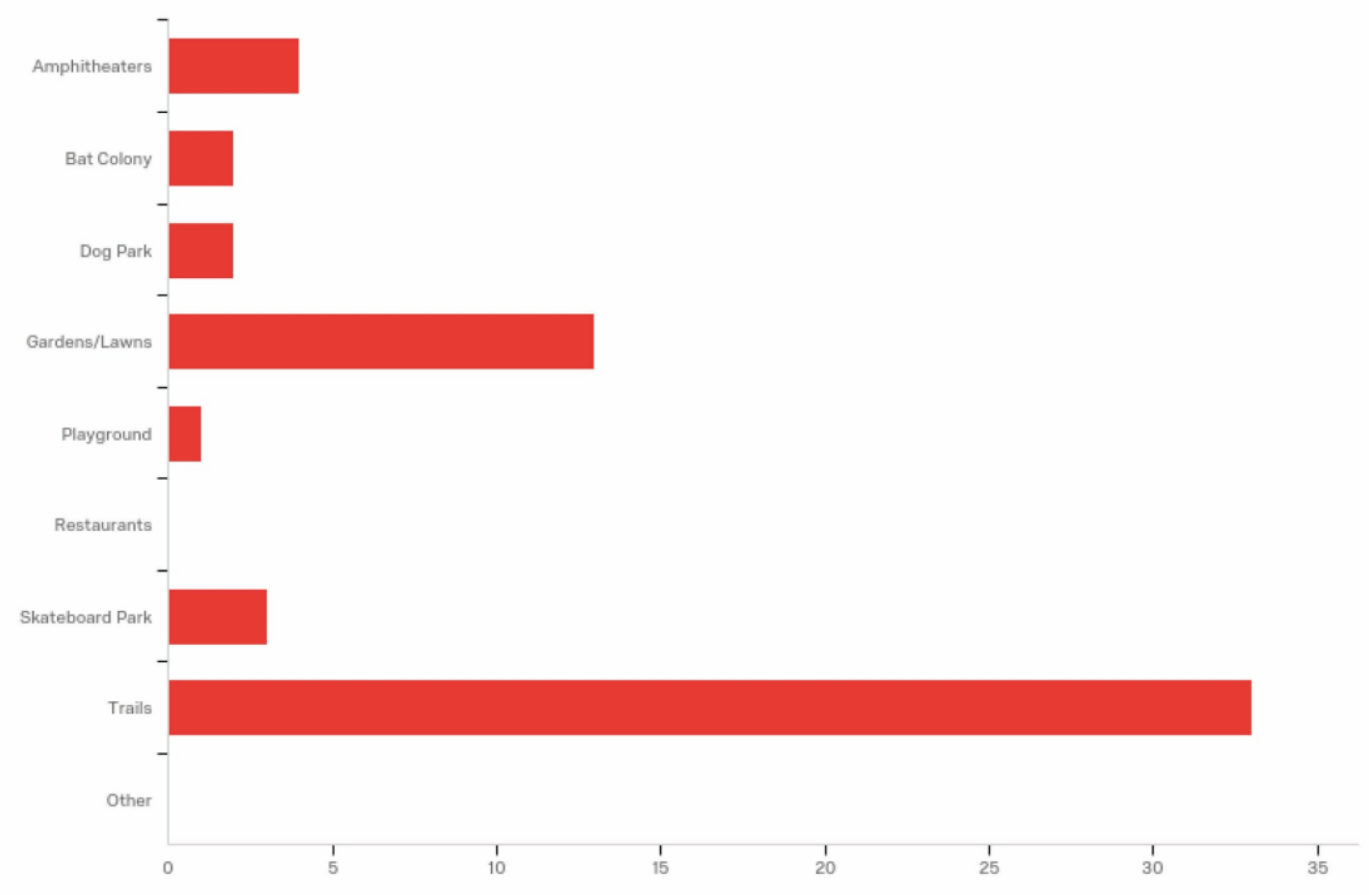


Q5 - How do you typically get to the park?

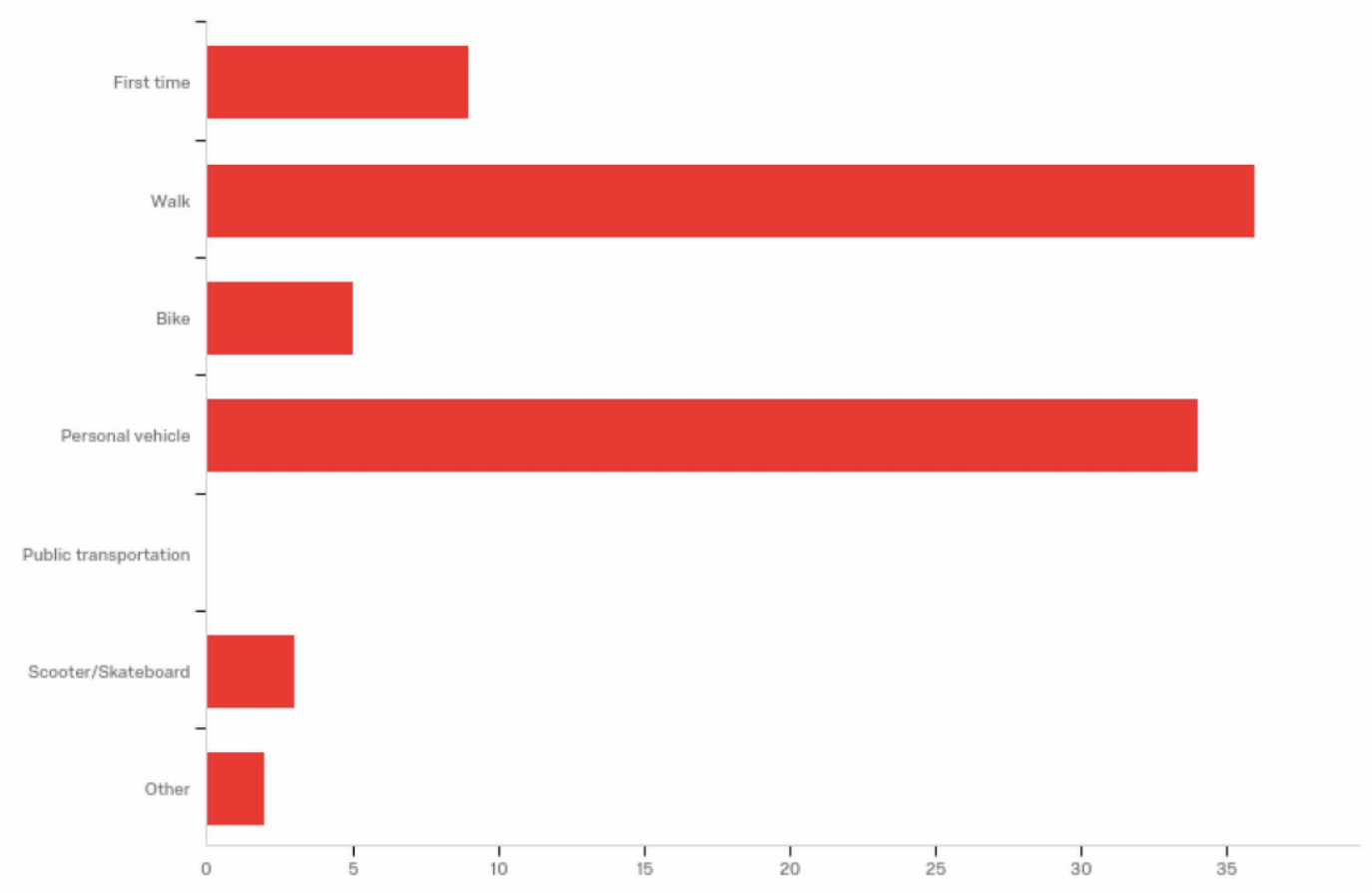


Q6 - How long did it/does it typically take you to the park? (Using that same mode)

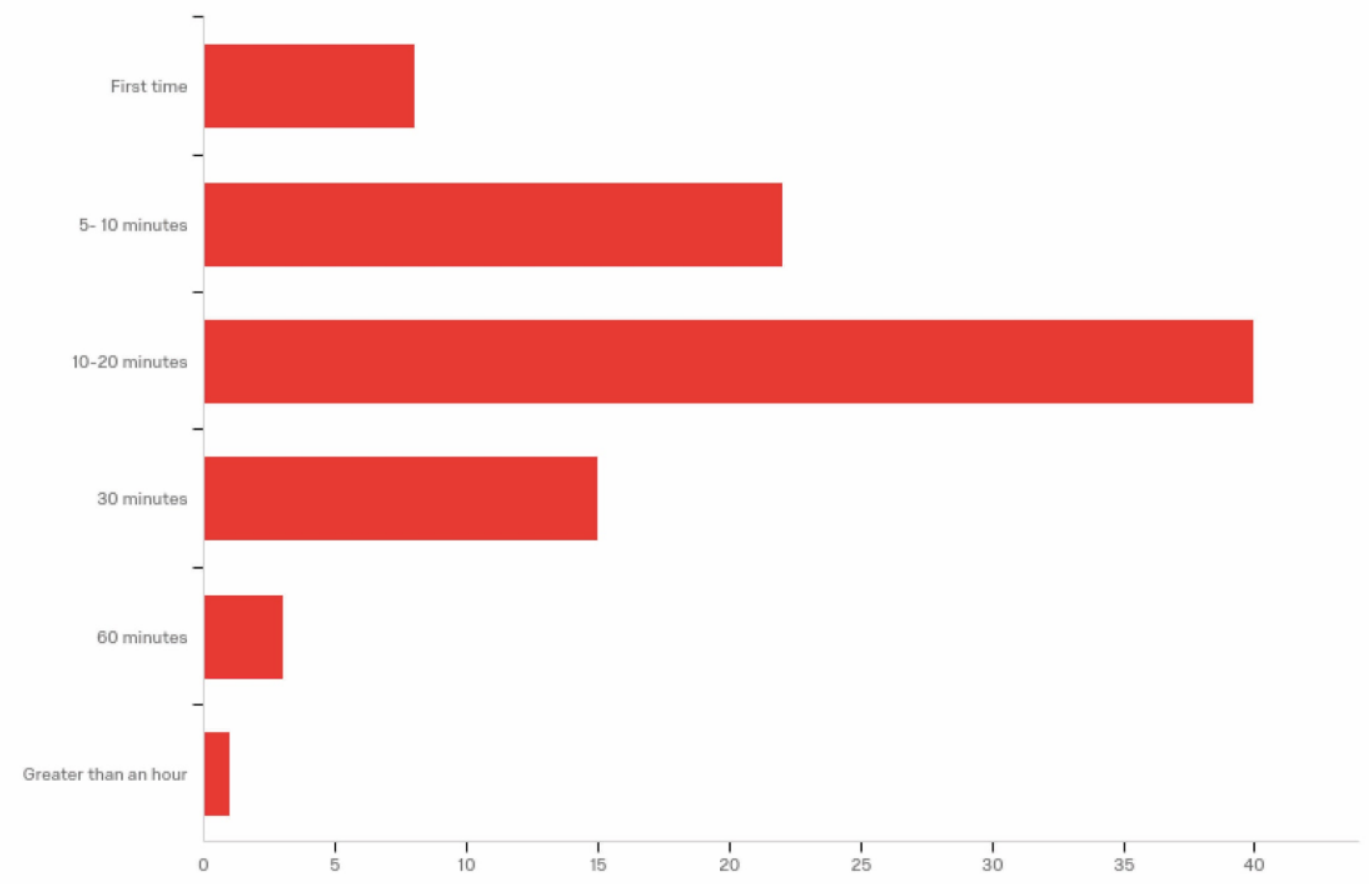


Q7 - Have you attended any events at the park? (Love Street Light Circus with Bayou Buddies, Buffalo Bayou Park Cistern Tour, Boat Tour, Walking Tour, Sunrise Yoga, etc.)

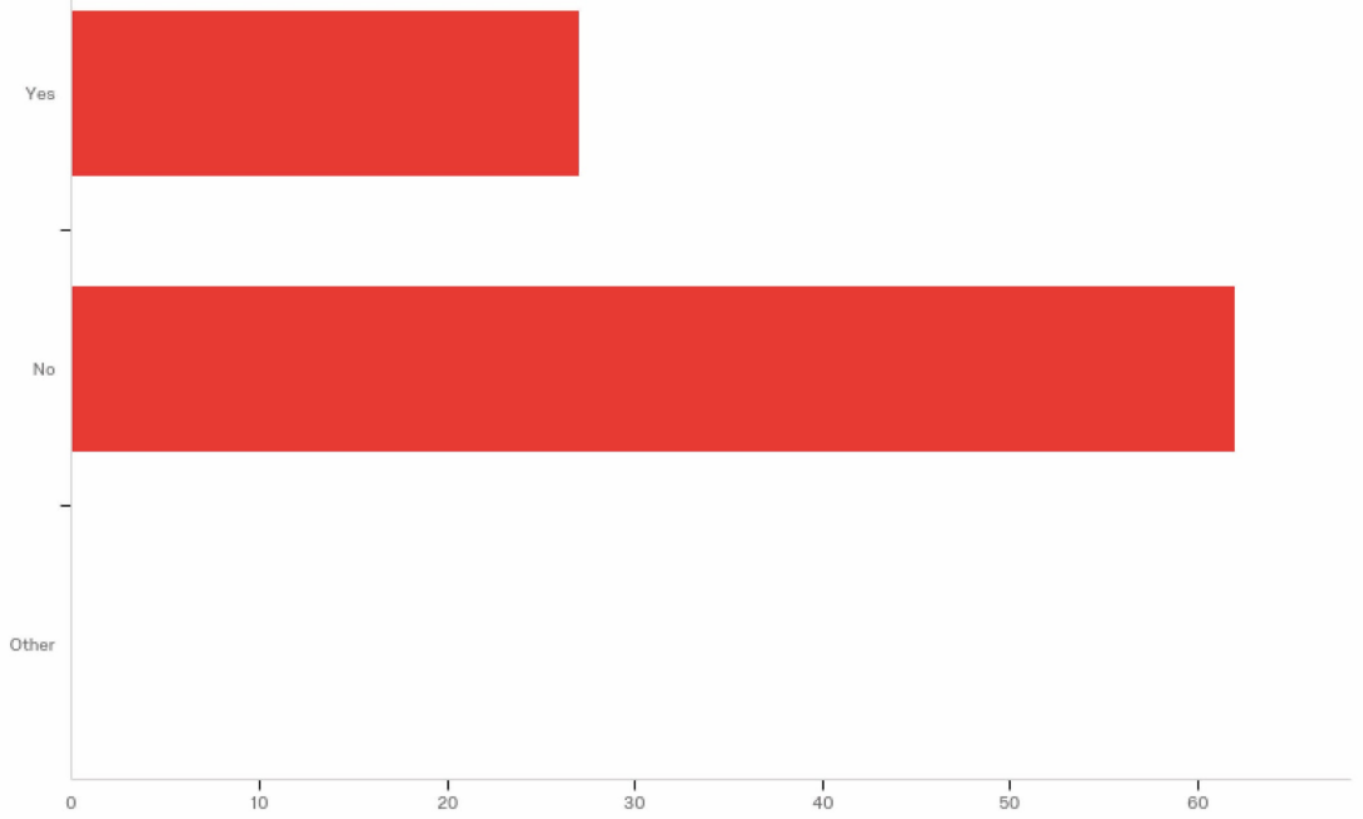


Q8 - Have you attended any educational activities in the Buffalo Bayou Park? (Information sessions, guided walking tours, boat tours, etc.)

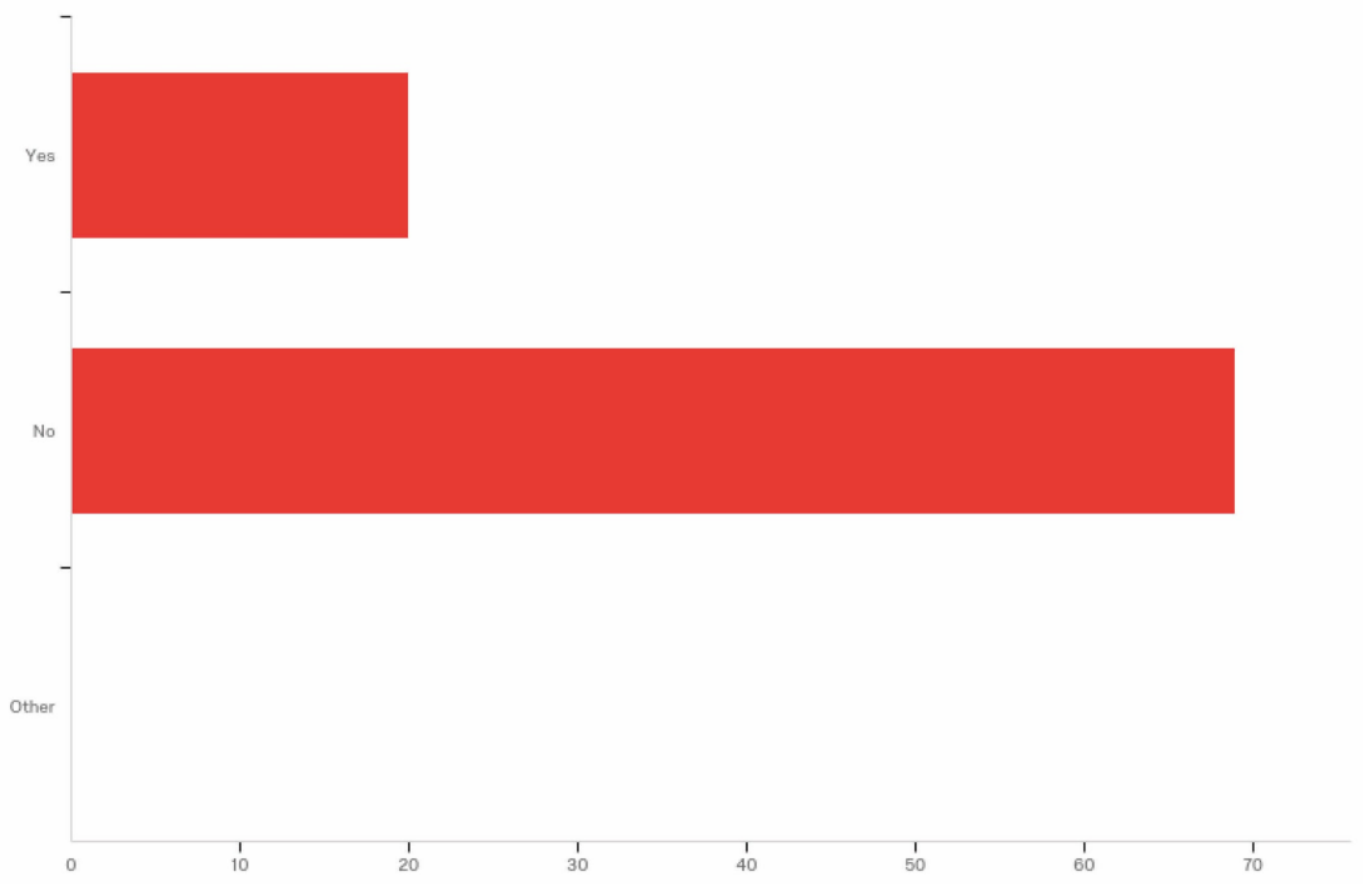


Q9 - Which of the following would you consider the most effective potential solution to protecting the bayou from flooding? (You may choose up to four)

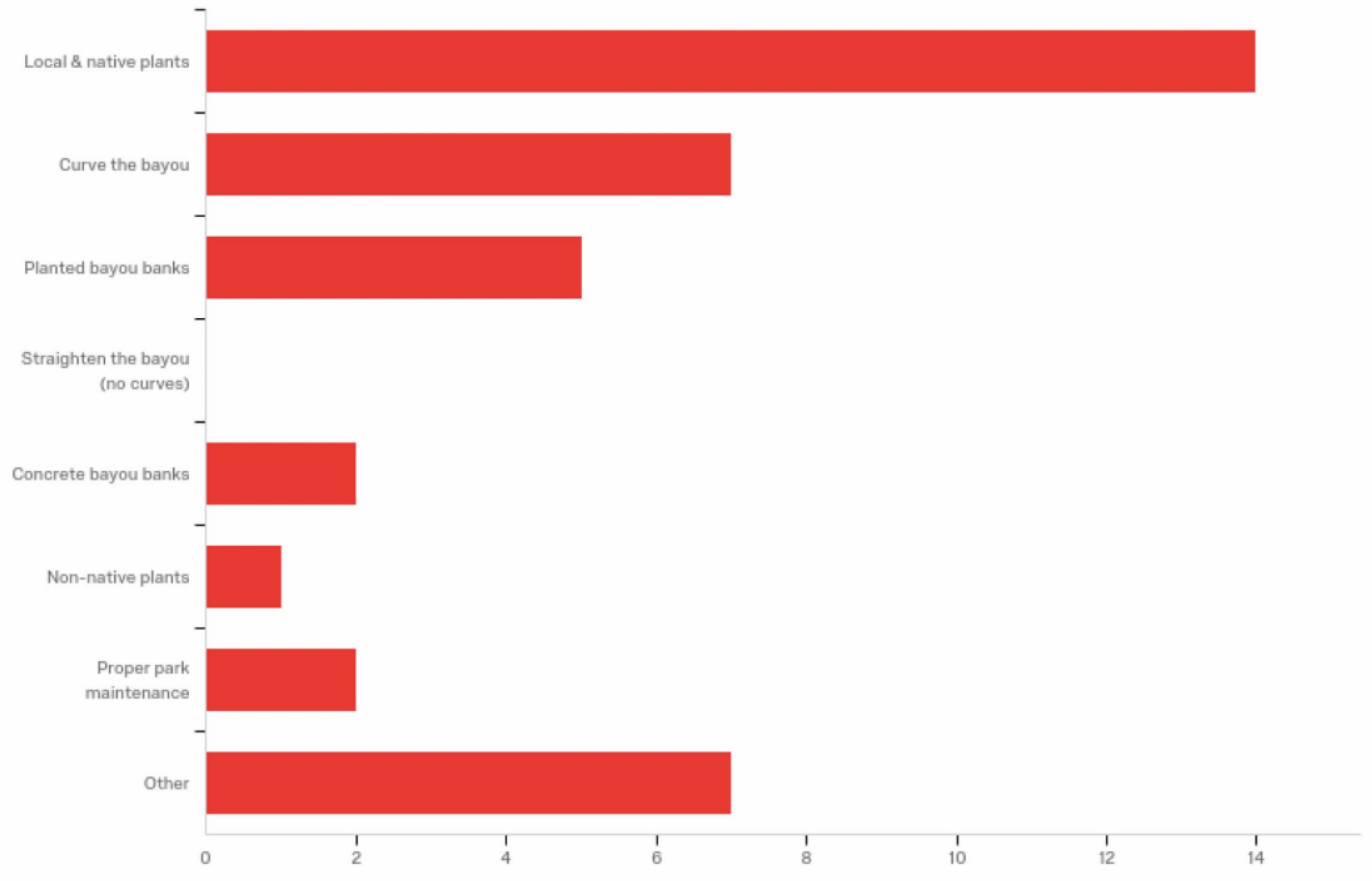


Q10 - How have you learned about flood protection with regard to Buffalo Bayou Park?

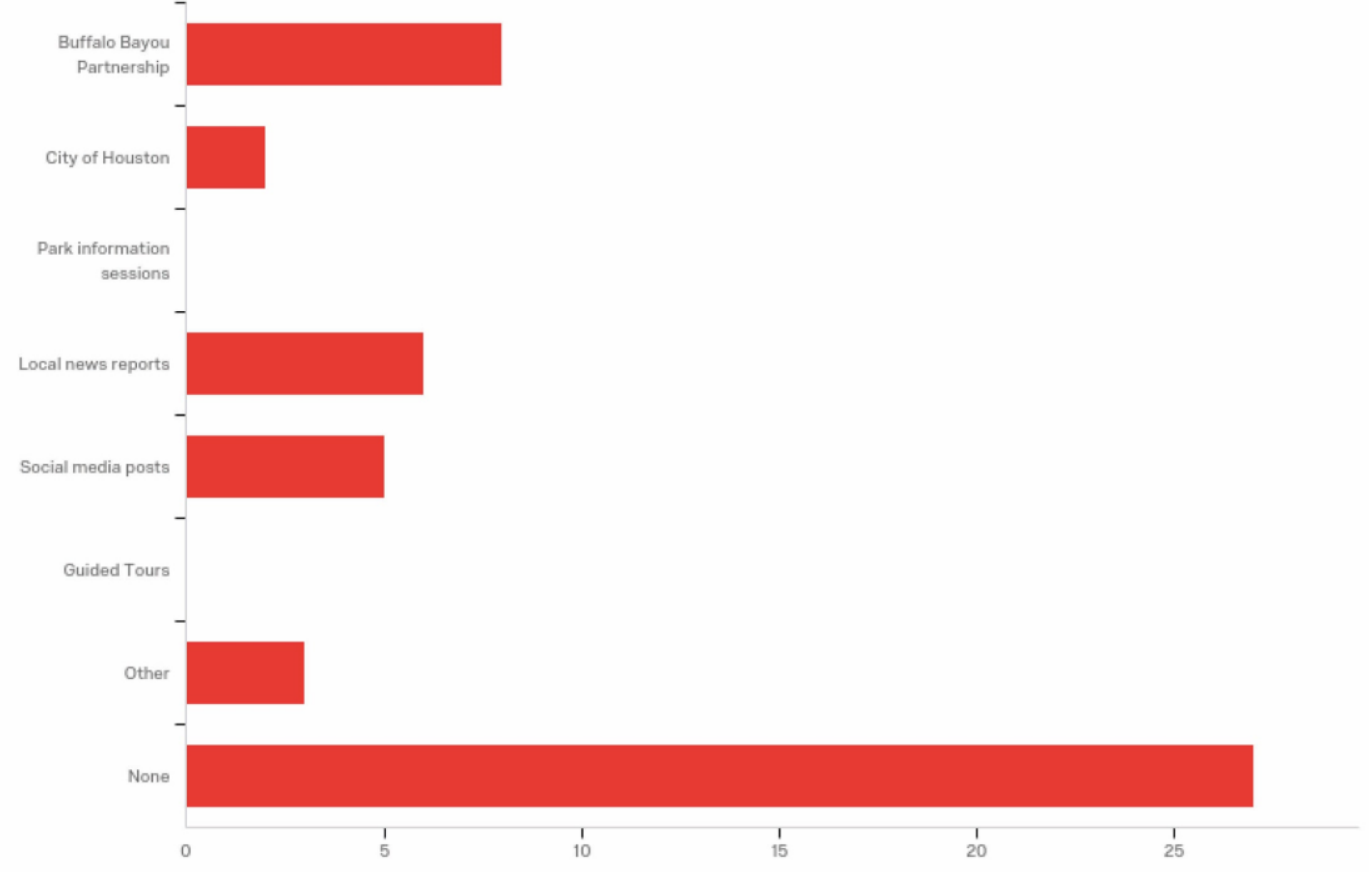


Q11 - Have you visited any nearby businesses/restaurants as part of your visit to the park?

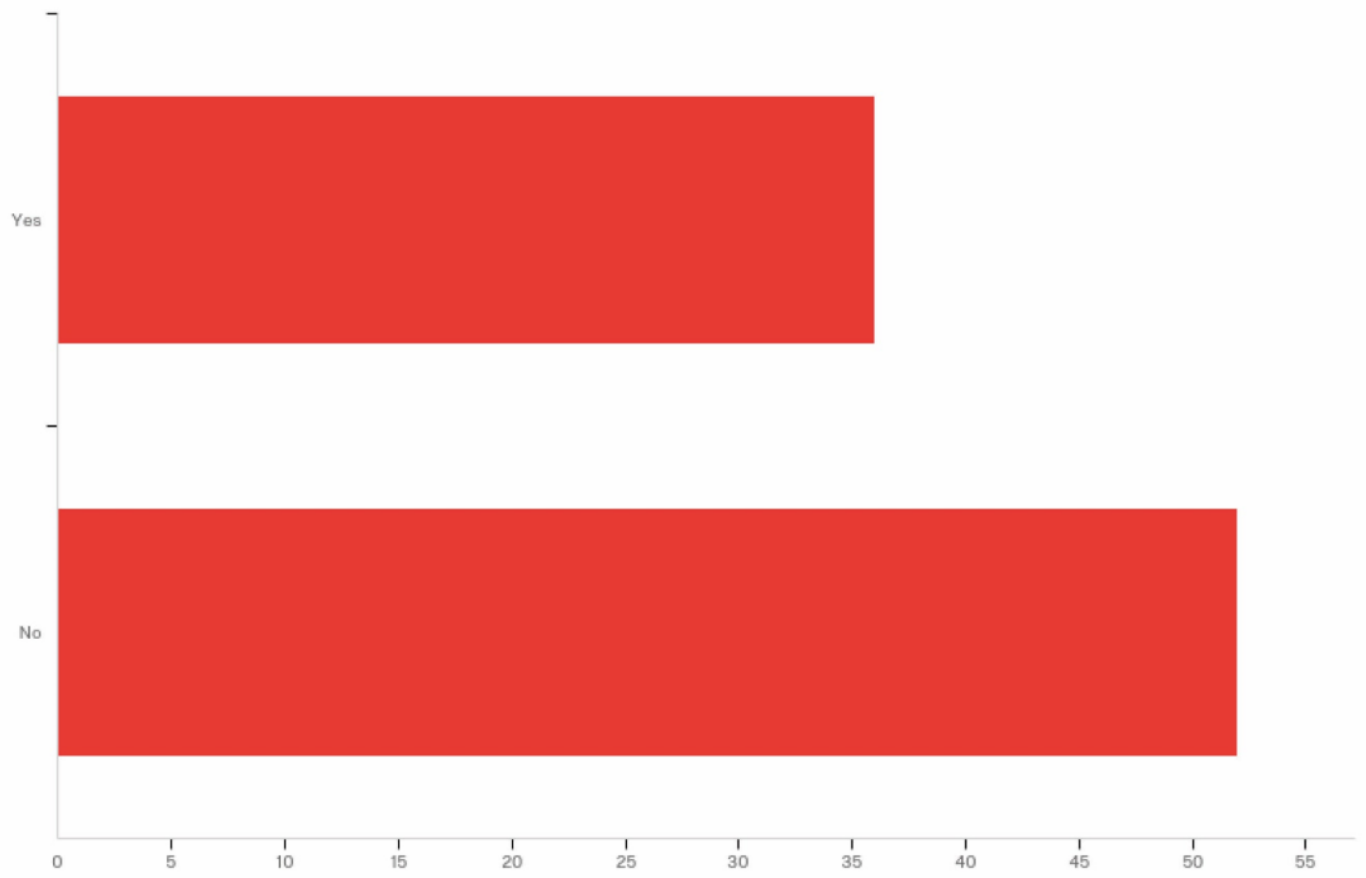


Q12 - How often do you visit nearby businesses/restaurants as part of your visit to the park?

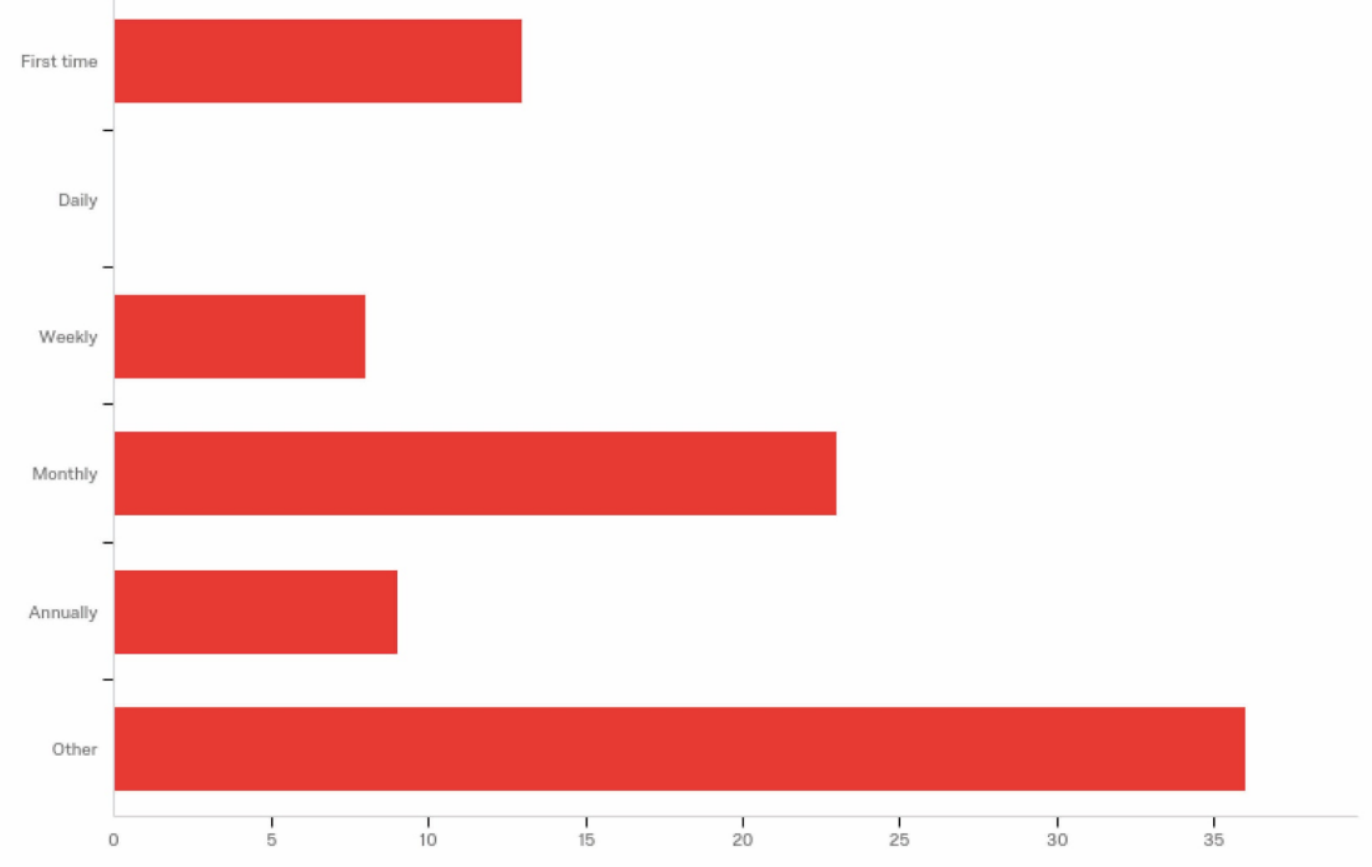


Q13 - Have you noticed a decrease in physical ailments such as, stress, asthma, and/or general poor health since you started coming to the park?

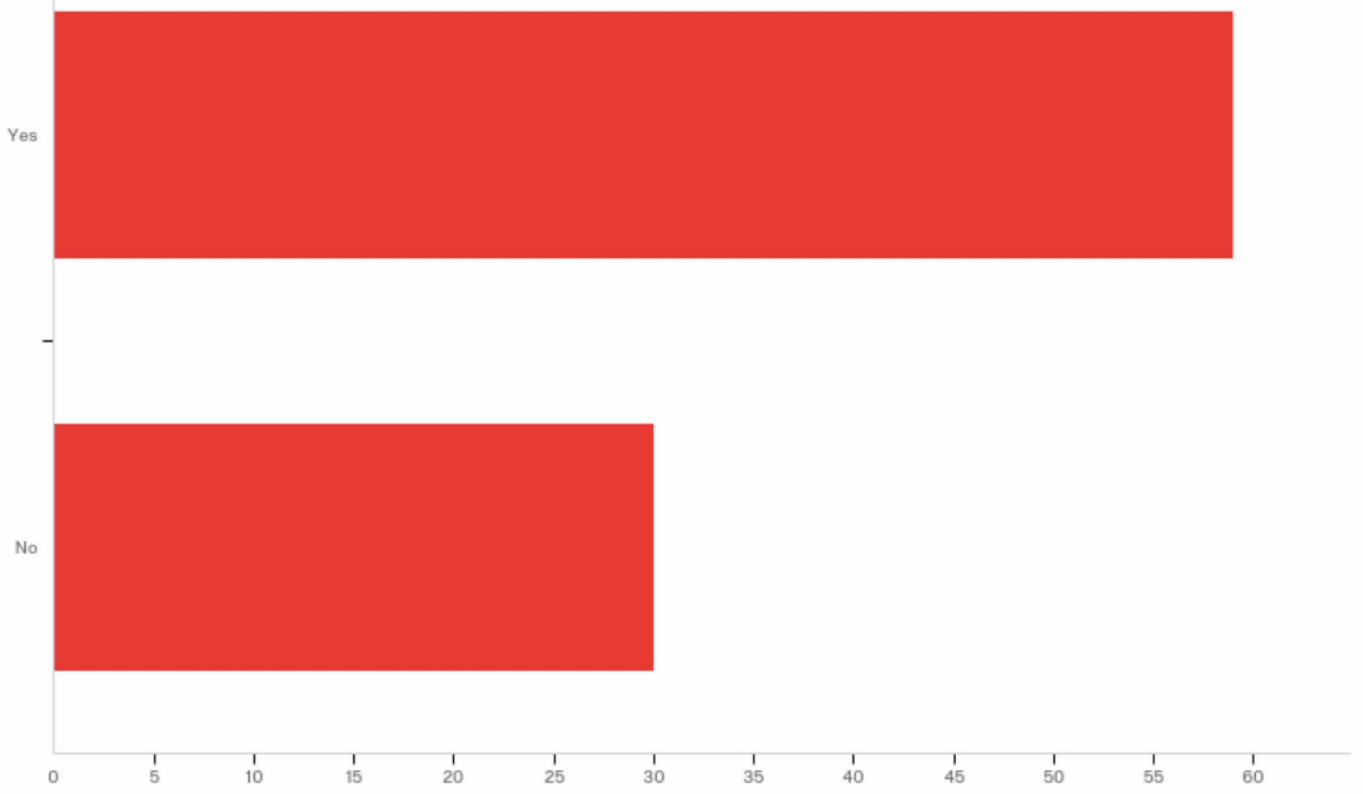


Q14\#1 - Could you rate the following statements regarding your experience with Buffalo Bayou Park? (1 is... - Ranking

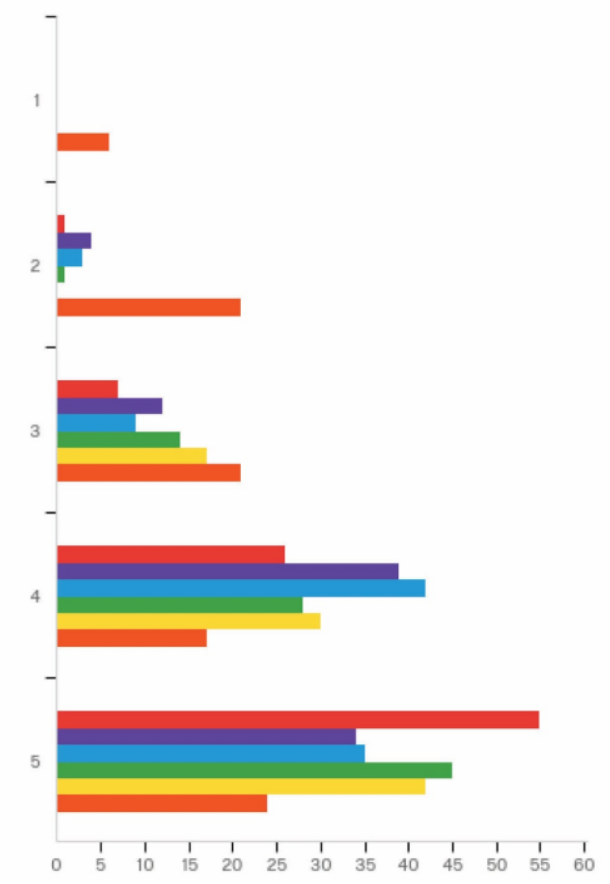

Visiting the park improves my quality of life and sense of well-being

Access to the park is easy

- The park provides diverse recreational activities

I I feel safe and secure when I am in the park

II I can describe the park as a pleasant place to be overall

- I have an understanding of the cultural and historical importance of the pa... 
QID21 - What is your age?

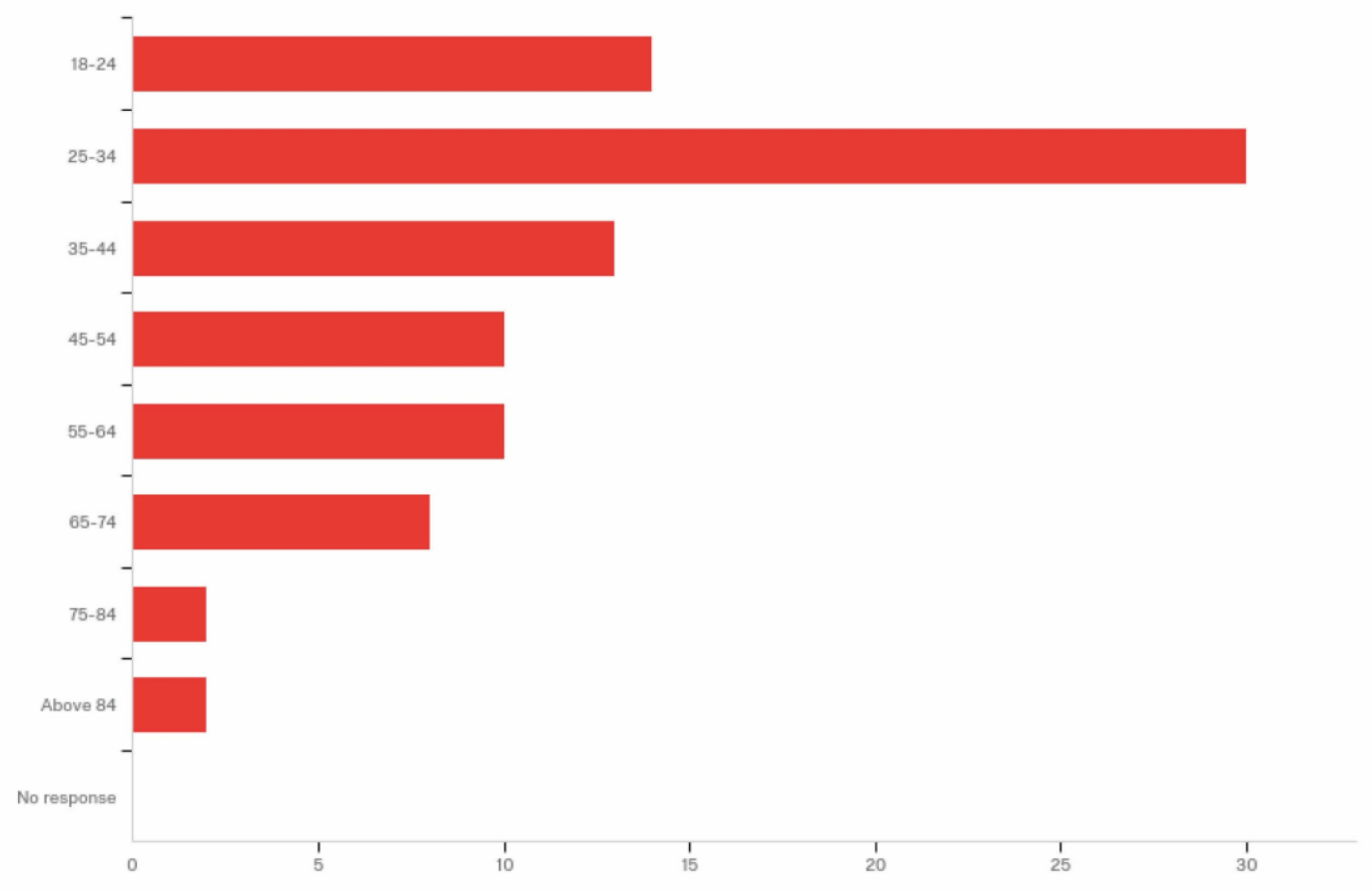


QID24 - Are you of Hispanic, Latino, or Spanish origin?

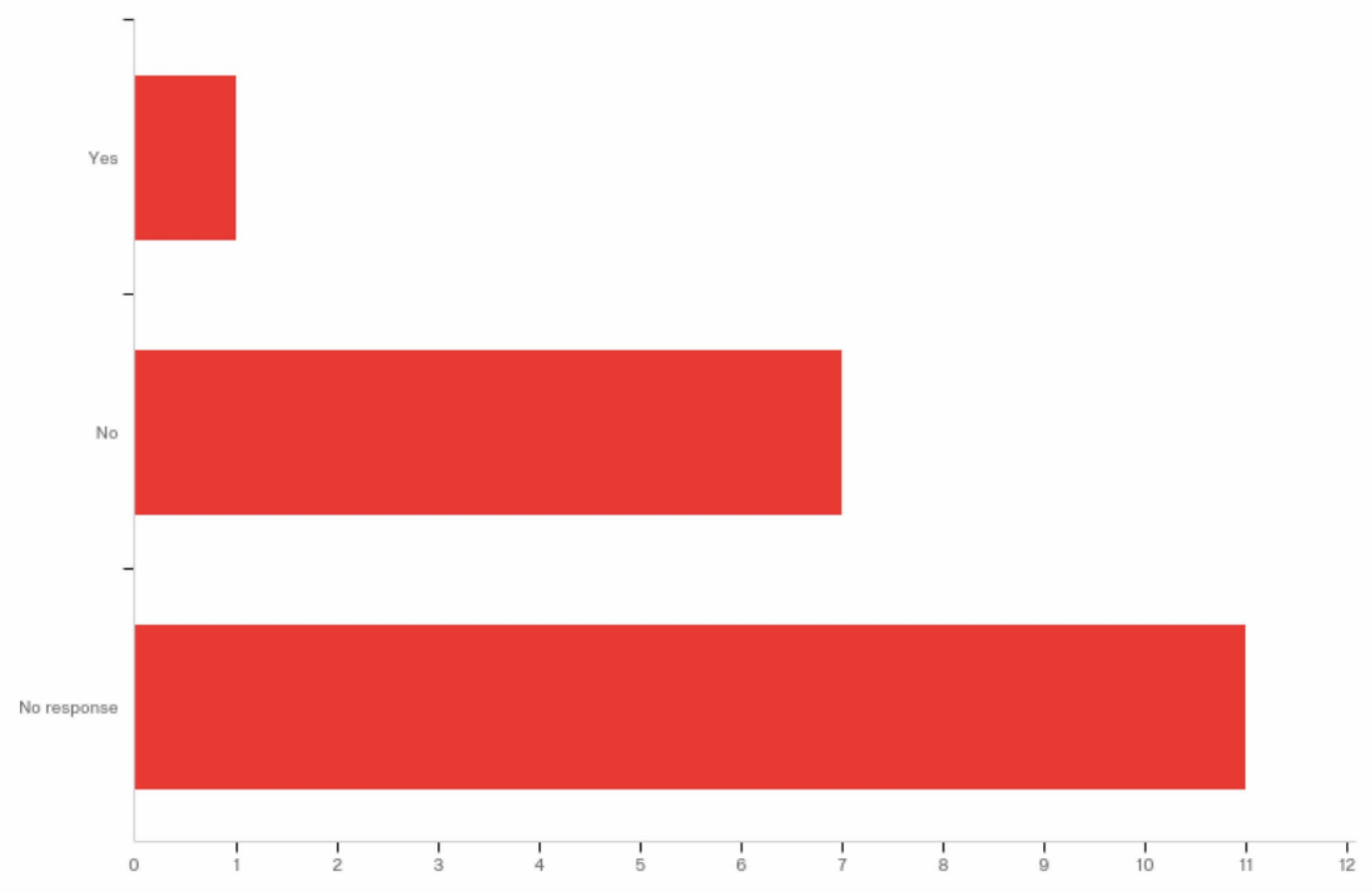

